\title{
Adaptability and Phenotypic Stability of Resistance to Two Viral Diseases and Yield Traits in Cassava
}

\section{Bernadetta Kimata1, Emily Masinde², Festo Masisila1, Rahim Menya1, Dwasi Matondo1, Midatharahally N. Maruthi ${ }^{3}$, Geoffrey Mkamilo ${ }^{*}$}

${ }^{1}$ Tanzania Agricultural Research Institute (TARI)-Naliendele, Mtwara, Tanzania

${ }^{2}$ Department of Crops Horticulture and Soils, Egerton University, Njoro, Kenya

${ }^{3}$ Natural Resources Institute, University of Greenwich, London, UK

${ }^{4}$ Tanzania Agricultural Research Institute (TARI)-Makutupora, Dodoma, Tanzania

Email: ^geoffreymkamilo@yahoo.co.uk

How to cite this paper: Kimata, B., Masinde, E., Masisila, F., Menya, R., Matondo, D., Maruthi, M.N. and Mkamilo, G. (2021) Adaptability and Phenotypic Stability of Resistance to Two Viral Diseases and Yield Traits in Cassava. American Journal of Plant Sciences, 12, 679-705.

https://doi.org/10.4236/ajps.2021.124046

Received: March 9, 2021

Accepted: April 26, 2021

Published: April 29, 2021

Copyright $\odot 2021$ by author(s) and Scientific Research Publishing Inc. This work is licensed under the Creative Commons Attribution International License (CC BY 4.0).

http://creativecommons.org/licenses/by/4.0/

(c) (i) Open Access

\begin{abstract}
Cassava productivity is hampered by pests and diseases including cassava mosaic disease (CMD) and cassava brown streak disease (CBSD). The main objective of this study was to identify stable superior genotypes that combine disease resistance and high yield. Sixteen cassava genotypes were planted in a randomized complete block design with three replications for six planting seasons (years) at five sites in Tanzania. The genotypes were assessed using the additive main effect and multiplicative interaction (AMMI) analysis, and highly significant $(\mathrm{P}<0.001)$ effects of genotype, environment, and genotypeby-environment $\left(G^{*} E\right)$ interactions were observed for all traits studied. Percent sum of squares (SS) due to environment (12.66\% - 85.23\%) was the highest followed by $G^{*} E(14.12 \%-39.56 \%)$ for CMD foliar symptoms, root weight and dry matter. On the other hand, \% SS due to genotype (52.14\% - 69.14\%) was highest followed by $G^{*} E(26.14 \%-35.91 \%)$ for CBSD foliar and root symptoms indicating that the environment and $G^{*} E$ greatly influenced trait expression. The most stable genotypes which combined disease resistance and high yield were NDL 2003/31 and NDL 2003/111. The findings of this study will give impetus for the release of new cassava varieties that are not only high yielding but are also dually resistant to both CMD and CBSD in different locations and sites.
\end{abstract}

\section{Keywords}

Cassava Brown Streak Disease, Cassava Mosaic Disease, Disease Resistance, Genotype Environment Interaction, High Yield 


\section{Introduction}

Cassava (Manihot esculenta Crantz) is a vital food staple in sub-Saharan Africa (SSA), ranked as the number one root crop, followed by sweet potato and yam [1]. With over 300 million MT of annual root production [1], cassava is a major source of carbohydrates in the diet of millions of people in SSA and is grown as a famine reserve crop owing to its tolerance of harsh environmental conditions [2] [3]. The crop also has industrial application as it is used to produce high-quality flour, starch, beverages, animal feeds, alcohol, biofuel, detergents, textiles, plastics and pharmaceutical products [4] [5] [6] [7].

Although Tanzania has the largest area $(885,091 \mathrm{ha})$ under cassava production in East Africa, its average yield is low at $5.7 \mathrm{t} / \mathrm{ha}$ [1], which is far below the estimated yield potential of cassava (50 - $60 \mathrm{t} / \mathrm{ha}$ ) [8]. This is due to many biotic and abiotic factors including the two viral diseases: cassava mosaic disease (CMD), and cassava brown streak disease (CBSD) [9] [10] [11]. Cassava roots affected by CBSD have a brown necrotic rot and are unfit for consumption. By contrast, storage roots of cassava plants severely affected by CMD fail to bulk because their leaves become chlorotic and mottled, thus having impeded photosynthesis and leading to stunted growth [12]. Dual infections of CMD and CBSD are common and a serious threat to cassava production and food security as losses more than $80 \%$ have been reported in susceptible varieties [13].

Deployment of cassava varieties with dual resistance to both diseases is currently being pursued as the most effective and sustainable way to manage the devastating effects of the viral diseases in Eastern and Southern Africa [14]. CMD, CBSD and yield traits expression in cassava can be influenced by the environment leading to varied phenotypes in different environments [15] [16] [17]. This is defined as genotype-by-environment $\left(G^{*} E\right)$ interaction [18] and it can result from differences in the sensitivities of genotypes to the conditions in the target environment [19]. This leads to inconsistent performances across different environments; therefore, limiting the efficiency of selection of superior genotypes.

The objective of most cassava improvement programmes is to identify and select diseases free, high yielding and stable genotypes across several environments and seasons. The efficiency and success of such selections depend on the consistency of the performances of genotypes in varying environments [20] [21]. For this reason, genotypes are tested in diverse environments to assess their adaptability and stability. Genotypes whose $G^{*} E$ effects are not significant are said to be stable [22]. Several methods have been used to assess the $G^{*} E$ effect and stability in crop performances including the additive main effect and multiplicative interaction (AMMI) model [23] [24].

The AMMI model fits the sum of several multiplicative terms rather than only one multiplicative term in assessing the performance of genotypes in different environments [25]. AMMI analysis can be used to determine the stability of the genotypes across locations using the PCA (principal component axis) scores and AMMI stability value (ASV) [26]. The ASV is based on the AMMI model's IPCA1 
and IPCA2 (interaction principal components axes 1 and 2), respectively scores for each genotype [27]. Genotypes having the least ASV are considered as widely adapted genotypes. Similarly, IPCA2 score near zero indicates more stable genotypes whilst large values represent more responsive and less stable genotypes.

However, the stability parameter alone does not give much information about the yield or performance of a genotype and cannot be used as the only selection parameter since most stable genotypes would not necessarily be the best with regards to desirable traits. Therefore, Jiwuba et al. [15], Nduwumuremyi et al. [28] and Tumuhimbise et al. [29] used yield stability index (YSI) and genotype stability index (GSI) which incorporate high yield or performance with stability. Both the YSI and the GSI are based on the sum of the ranking due to ASV scores and yield or performance ranking. Low GSI value indicates desirable genotypes with high mean yield or performance and stability.

The main aim of this research was to analyze the effects of $G^{*} E$ interaction on resistance to CMD, CBSD and yield traits on 16 cassava genotypes using the AMMI model. The specific objectives were to 1) Identify superior genotypes that exhibit high stability which combine CMD and CBSD resistance and high yield; 2) Identify environments that best represent the target environment for high expression of the traits.

\section{Materials and Methods}

\subsection{Study Location and Germplasm}

The study was done in five sites: Chambezi, Mtopwa, Nachingwea, Naliendele and Mtopwa for six planting seasons (2013, 2014, 2015, 2016, 2017 and 2018) (Table 1). Advanced breeding lines including released improved varieties and local landraces were evaluated in the study (Table 2). The advanced breeding lines and improved varieties were obtained from the TARI-Naliendele or the

Table 1. Sites description.

\begin{tabular}{|c|c|c|c|c|c|}
\hline \multirow{2}{*}{ Descriptions } & \multicolumn{5}{|c|}{ Sites } \\
\hline & Chambezi [42] [43] & Mtopwa [44] & Nachingwea [44] & Naliendele [44] & Segera $[45][46]$ \\
\hline Site location & $\begin{array}{l}\text { Coastal belt of } \\
\text { the Indian Ocean }\end{array}$ & Makonde plateau & $\begin{array}{c}\text { Masasi-Nachingwea } \\
\text { plains }\end{array}$ & $\begin{array}{l}\text { Coastal belt of } \\
\text { the Indian Ocean }\end{array}$ & $\begin{array}{l}\text { Dry plains of Handeni } \\
\text { district in Tanga region }\end{array}$ \\
\hline Co-ordinates & $06^{\circ} 55^{\prime} \mathrm{S}, 38^{\circ} 91^{\prime} \mathrm{E}$ & $10^{\circ} 41^{\prime} \mathrm{S}, 39^{\circ} 23^{\prime} \mathrm{E}$ & $10^{\circ} 20^{\prime} \mathrm{S}, 38^{\circ} 46^{\prime} \mathrm{E}$ & $10^{\circ} 22^{\prime} \mathrm{S}, 40^{\circ} 10^{\prime} \mathrm{E}$ & $05^{\circ} 31^{\prime} \mathrm{S}$ and $38^{\circ} 54^{\prime} \mathrm{E}$ \\
\hline Altitude & $46 \mathrm{~m}$ & $760 \mathrm{~m}$ & $465 \mathrm{~m}$ & $111 \mathrm{~m}$ & $290 \mathrm{~m}$ \\
\hline Soil Type & Ferralic Cambisol & $\begin{array}{c}\text { Veti-acric } \\
\text { Ferrasols - Xanthic }\end{array}$ & $\begin{array}{c}\text { Veti-acric } \\
\text { Ferrasols - Rhodic }\end{array}$ & $\begin{array}{c}\text { Veti-acric } \\
\text { Ferrasols - Xanthic }\end{array}$ & $\begin{array}{l}\text { Rhodic Ferrasols } \\
\text { (Orthic, Xanthic) }\end{array}$ \\
\hline Soil texture & Sandy soils & $\begin{array}{c}\text { Deep, highly } \\
\text { weathered, well drained } \\
\text { sandy clay loam }\end{array}$ & $\begin{array}{c}\text { Deep, highly } \\
\text { weathered, red } \\
\text { sandy clay loam }\end{array}$ & $\begin{array}{l}\text { Deep, highly } \\
\text { weathered, well } \\
\text { drained sandy } \\
\text { clay loam }\end{array}$ & $\begin{array}{l}\text { Well drained, moderately deep or } \\
\text { deep reddish and yellowish } \\
\text { sandy clay loam to clay. } \\
\text { Well-structured soil with low fertility }\end{array}$ \\
\hline SoiI pH & $5.0-7.0$ & $4.5-6.5$ & $4.5-8.2$ & $4.5-6.5$ & $5.5-7.5$ \\
\hline
\end{tabular}


Table 2. Pedigree and status of advanced breeding lines and local cassava cultivars.

\begin{tabular}{|c|c|c|c|c|}
\hline Genotype & Female parent & Male parent & Remarks & Status \\
\hline Albert & Unknown & Unknown & $\begin{array}{l}\text { Putative fullsib } \\
\text { TME } 117\end{array}$ & Local landrace \\
\hline KBH 2002/26 (Mkuranga 1) & КBH 95/082 & Unknown & Halfsib & Released \\
\hline KBH 2002/477 & Kiroba & Unknown & Halfsib & Not released \\
\hline KBH 2002/482 (Kizimbani) & Kiroba & Unknown & Halfsib & Released \\
\hline KBH 2002/494 & Kiroba & Unknown & Halfsib & Not released \\
\hline KBH 2002/66 (Kipusa) & $196 / 1632$ & Unknown & Halfsib & Released \\
\hline КВН 96/1056 & Kiroba & Unknown & Halfsib & $\begin{array}{l}\text { Candidate line for } \\
\text { official release }\end{array}$ \\
\hline Kiroba & Unknown & Unknown & Halfsib & Released \\
\hline Mahiza & Unknown & Unknown & Halfsib & Local landrace \\
\hline Mkumba & Namikonga & AR42-4 & Fullsib & Released \\
\hline Naliendele 034 & Kibaha & Unknown & Halfsib & $\begin{array}{l}\text { Released but CBSD } \\
\text { resistance broken }\end{array}$ \\
\hline NDL $2003 / 111$ & Namikonga & Kalulu & Fullsib & $\begin{array}{l}\text { Candidate line for } \\
\text { official release }\end{array}$ \\
\hline NDL 2003/031 & Nachinyaya & Kiroba & Fullsib & $\begin{array}{l}\text { Candidate line for } \\
\text { official release }\end{array}$ \\
\hline NDL 2005/1471 & Nachinyaya & Unknown & Halfsib & $\begin{array}{l}\text { Candidate line for } \\
\text { official release }\end{array}$ \\
\hline NDL 2005/1472 & Nachinyaya & Unknown & Halfsib & $\begin{array}{l}\text { Candidate line for } \\
\text { official release }\end{array}$ \\
\hline Pwani & Namikonga & AR42-4 & Fullsib & Released \\
\hline
\end{tabular}

Fullsib-genotypes with known male and female parents; Halfsib-genotypes with a known mother that was open pollinated hence male parent is unknown.

International Institute for Tropical Agriculutre's breeding programmes, while the local landraces were obtained from farmers' fields.

\subsection{Experimental Design}

A randomized complete block design with three replicates was used for this study. Cassava cuttings (about $25 \mathrm{~cm}$ long with 4 to 5 nodes and viable buds) from each of the genotypes were planted in 4 rows with 10 cuttings each at a spacing of $1.0 \mathrm{~m} \times 1.0 \mathrm{~m}$, resulting in a total of 40 plants/plot/replicate. To increase disease inoculum pressure, susceptible cassava varieties Albert and Limbanga were planted as spreader rows for CBSD and CMD, respectively [30]. Albert and Limbanga cutting were planted alternately after every 8 plots and as a border row around each replicate. Released varieties and landraces including Albert, Kiroba, Pwani, Mahiza, Mkumba and Naliendele 134 were planted as controls in the experiment. Neither fertilizer nor irrigation was applied; the field was rain-fed throughout the growing period but was kept weed-free. 


\subsection{Data Collection}

Data on several parameters were collected including CMD and CBSD foliar severity at 3,6, and 9 MAP; root necrosis; root weight $(\mathrm{t} / \mathrm{ha})$, and dry matter content during harvest at $12 \mathrm{MAP}$. CMD foliar severity was scored on a $1-5$ scale where: $1=$ no visible symptoms; 2 = mild distortion only at the base of leaflets with the rest of leaflets appearing green and healthy/mild chlorotic pattern over entire leaflets; 3 = conspicuous mosaic pattern throughout the leaf, narrowing and distortion of lower $1 / 3$ of leaflets; $4=$ severe mosaic, distortion of two-thirds of leaflets and general reduction of leaf size; and $5=$ severe mosaic, distortion of $3 / 4$ of leaflets, twisted and malformed leaves [31].

CBSD foliar severity was scored on a $1-5$ scale where: $1=$ no visible symptoms; 2 = mild foliar mosaic on some leaves and no stem lesions; 3 = foliar mosaic with mild stem lesions and no die back; $4=$ foliar mosaic and pronounced stem lesions and no dieback; and $5=$ defoliation with pronounced stem lesions and dieback [32]. At 12 MAP, plants were harvested, and roots were examined for CBSD root symptoms. Roots from each plant were chopped longitudinally and transversely to identify the presence of necrotic patches on the starch bearing tissues. Scoring for root necrosis severity was also done based on a 1 - 5 where: $1=$ no clear symptoms; $2=<5 \%$ of root necrotic; $3=5 \%-25 \%$ of root necrotic; $4=25 \%-50 \%$ root necrotic and mild root constriction; and $5=>50 \%$ of root necrotic [32] [33] [34]. Roots from each plant were harvested and chopped longitudinally and transversely to check for root necrosis on the starch bearing tissues. Root weight in tonnes per hectare ( $\mathrm{t} / \mathrm{ha}$ ) was estimated according to Masinde et al. [16] while root dry matter content using the specific gravity method [35].

$$
\operatorname{Root} \text { weight }(\mathrm{t} / \mathrm{ha})=\frac{\text { Root weight }\left(\frac{\mathrm{kg}}{\mathrm{m}^{2}}\right) \times 10000}{1000}
$$

Dry matter content $=158.3 \times\left[\frac{\text { Weight of roots in air }}{\text { Weight of roots in air }- \text { Weight of roots in water }}\right]-142$

\subsection{Data Analysis}

The AMMI model was used to determine the stability of the genotypes across environments. The AMMI model first fits the additive effects for the genotypes and the growing environments (five growing sites and six seasons) and multiplicative term for $G^{*} E$ interactions. The AMMI model according to Gauch [36] and Farshadfar et al. [37] is presented as

$$
Y_{i j}=\mu+g_{i}+e_{j}+\sum_{k=1}^{n} \lambda_{k} \alpha_{i k} \gamma_{j k}+e_{i j}
$$

where

$$
\begin{aligned}
& Y_{i j}=\text { Phenotypic trait e.g. yield of the } i^{\text {th }} \text { genotype in the } j^{\text {th }} \text { environment } \\
& \mu=\text { Grand mean } \\
& g_{i} \text { and } e_{j}=\text { Genotype and environment deviations from the grand mean, }
\end{aligned}
$$


respectively

$k=$ The number of principal components retained in the model

$\lambda_{k}=$ The eigenvalue of the PCA axis $k$

$\alpha_{i k}$ and $\gamma_{j k}=$ the principal component scores for PCA axis $k$ of the $i^{\text {th }}$ genotype and the $j^{\text {th }}$ environment, respectively

$e_{i j}=$ Residual

The ASV was calculated for each genotype according to the relative contributions of IPCA1 and IPCA 2 to the interaction sum of squares. The ASV has been defined as the distance from the coordinate point to the origin in a two-dimensional scatterplot of the first IPCA1 scores against the second IPCA2 [27] [38]. The IPCA1 accounts for most of the $G^{*} E$ variation. The IPCA1 scores are weighted by the ratio of IPCA1 SS (from the AMMI ANOVA) to IPCA2 SS in the ASV formula as

$$
\mathrm{ASV}=\sqrt{\left[\frac{\text { IPCA } 1_{\text {sumofsquares }}}{\text { IPCA2 }_{\text {sumofsquares }}}\left(\text { IPCA } 1_{\text {score }}\right)\right]^{2}+\left(\text { IPCA } 2_{\text {score }}\right)^{2}}
$$

The larger the IPCA score is, either negative or positive, the more adapted a genotype is to a certain environment. Smaller ASV scores indicate a more stable genotype across environments [39]. Genotype stability index (GSI) was also calculated using the sum of the ranking based on trait and ranking based on the AMMI stability value. GSI incorporates both the mean and stability of the trait being studied in a single criterion. Low values of both parameters show suitable genotypes for example those with high mean yield and stability [29] [40]. Both AMMI and biplot analysis were computed using the R package Agricolae [41].

$$
\mathrm{GSI}=\mathrm{RASV}+\mathrm{RY} \text {, }
$$

where

RASV = Rank of the genotypes based on the AMMI stability value,

$\mathrm{RY}=$ Rank of the genotypes based on yield across environments.

\section{Results}

\subsection{CMD Foliar Symptoms}

The results of the combined AMMI analysis of variance revealed highly significant $(\mathrm{P} \leq 0.001)$ effects of genotype, environment and $G^{*} E$ for CMD foliar symptoms at 3, 6, and 9 MAP (Table 3). Percent sum of squares (SS) due to environment $(41.04 \%$ - $42.61 \%)$ was higher than \% SS due to $G^{*} E(30.19 \%$ $36.35 \%)$ and genotype $(22.61 \%-27.24 \%)$ indicating that environment greatly influenced the expression of CMD symptoms. $G^{*} E$ interaction SS was partitioned into four significant Interactive Principal Components Axes (IPCAs) for CMD 3 MAP while CMD 6 and 9 MAP had three significant IPCAs. IPCA1 and IPCA2 accounted for a total SS of $67.88 \%, 80.5 \%$ and $73.19 \%$ of the $G^{*} E$ variation for CMD at 3, 6 and 9 MAP, respectively. This justified the use of AMMI2 (IPCA2 vs IPCA1) biplot model for CMD foliar symptoms. The mean CMD foliar symptoms were $1.17,1.24$ and 1.21 at 3,6 , and 9 MAP, respectively (Table S1). A 
Table 3. Combined AMMI ANOVA for CMD and CBSD foliar symptoms at 3, 6, and 9 MAP of 16 cassava genotypes evaluated across 30 environments ( 6 planting seasons $\times 5$ sites).

\begin{tabular}{|c|c|c|c|c|c|c|c|}
\hline \multirow[b]{2}{*}{ Source } & \multirow[b]{2}{*}{ df } & \multicolumn{6}{|c|}{ Mean squares } \\
\hline & & $\begin{array}{l}\text { CMD } 3 \\
\text { MAP }\end{array}$ & $\begin{array}{l}\text { CMD } 6 \\
\text { MAP }\end{array}$ & $\begin{array}{c}\text { CMD } 9 \\
\text { MAP }\end{array}$ & $\begin{array}{c}\text { CBSD } 3 \\
\text { MAP }\end{array}$ & $\begin{array}{c}\text { CBSD } 6 \\
\text { MAP }\end{array}$ & $\begin{array}{c}\text { CBSD } 9 \\
\text { MAP }\end{array}$ \\
\hline Treatment & 479 & $0.19^{\star * \star}$ & $0.36^{* * *}$ & $0.26^{* * *}$ & $0.88^{\star * *}$ & $1.26^{\star * \star}$ & $1.02^{* * *}$ \\
\hline Genotype $(G)$ & 15 & $1.37^{* * *}$ & $2.92^{\star * *}$ & $2.23^{* * *}$ & $17.15^{\star * *}$ & $25.70^{\star \star *}$ & $22.43^{* * *}$ \\
\hline Environment $(E)$ & 29 & $1.28^{\star * \star}$ & $2.54^{\star * \star}$ & $1.80^{* * *}$ & $0.61^{* * *}$ & $1.30^{\star * \star}$ & $0.79^{* * *}$ \\
\hline Block & 60 & $0.08^{\star * *}$ & $0.10^{*}$ & $0.08^{* * *}$ & 0.11 & $0.16^{*}$ & 0.09 \\
\hline Interaction $\left(G^{*} E\right)$ & 435 & $0.08^{\star * *}$ & $0.13^{* * *}$ & $0.09^{* * *}$ & $0.34^{* * *}$ & $0.42^{\star * *}$ & $0.29^{* * *}$ \\
\hline IPCA1 & 43 & $0.33^{* * *}$ & $0.58^{* * *}$ & $0.38^{* * *}$ & $1.43^{* * *}$ & $1.73^{\star * *}$ & $1.09^{* * *}$ \\
\hline IPCA2 & 41 & $0.20^{\star * *}$ & $0.48^{\star * *}$ & $0.27^{\star * *}$ & $0.83^{\star \star \star}$ & $1.36^{\star * *}$ & $0.84^{* * *}$ \\
\hline IPCA3 & 39 & $0.13^{* * *}$ & $0.11^{*}$ & $0.11^{* * *}$ & $0.39^{* * *}$ & $0.47^{*}$ & $0.27^{* * *}$ \\
\hline IPCA4 & 37 & $0.05^{\star}$ & 0.06 & 0.05 & $0.35^{*}$ & 0.34 & $0.28^{*}$ \\
\hline IPCA5 & 35 & 0.03 & 0.04 & 0.04 & 0.22 & 0.25 & 0.24 \\
\hline \multirow[t]{2}{*}{ Error } & 899 & 0.03 & 0.07 & 0.04 & 0.13 & 0.11 & 0.09 \\
\hline & & \multicolumn{6}{|c|}{ Sum of squares } \\
\hline Treatment & 479 & 90.70 & 172.62 & 122.59 & 422.50 & 603.30 & 486.50 \\
\hline Genotype $(G)$ & 15 & 20.51 & 43.87 & 33.40 & 257.32 & 385.55 & 336.38 \\
\hline Environment $(E)$ & 29 & 37.22 & 73.55 & 52.18 & 17.68 & 37.72 & 22.94 \\
\hline Block & 60 & 4.47 & 6.16 & 4.99 & 6.31 & 9.83 & 5.34 \\
\hline Interaction $\left(G^{*} E\right)$ & 435 & 32.97 & 55.20 & 37.01 & 147.50 & 180.03 & 127.18 \\
\hline IPCA1 & 43 & 14.08 & 24.95 & 16.16 & 61.59 & 74.45 & 46.91 \\
\hline IPCA2 & 41 & 8.30 & 19.49 & 10.96 & 33.82 & 55.93 & 34.26 \\
\hline IPCA3 & 39 & 5.11 & 4.17 & 4.26 & 15.15 & 18.23 & 10.58 \\
\hline IPCA4 & 37 & 1.98 & 2.21 & 2.00 & 12.90 & 12.67 & 10.39 \\
\hline IPCA5 & 35 & 1.20 & 1.52 & 1.32 & 7.73 & 8.78 & 8.44 \\
\hline Error & 899 & 31.2 & 63.66 & 38.18 & 119.73 & 100.08 & 81.62 \\
\hline$\%$ treatment SS due to $G$ & & 22.61 & 25.41 & 27.24 & 60.90 & 63.90 & 69.14 \\
\hline$\%$ treatment SS due to $E$ & & 41.04 & 42.61 & 42.56 & 4.18 & 6.25 & 4.72 \\
\hline$\%$ treatment SS due to $G^{*} E$ & & 36.35 & 31.98 & 30.19 & 34.91 & 29.84 & 26.14 \\
\hline$\% G^{*} E$ SS due to IPCA1 & & 42.71 & 45.20 & 43.66 & 41.76 & 41.35 & 36.89 \\
\hline$\% G^{*} E \mathrm{SS}$ due to IPCA2 & & 25.17 & 35.31 & 29.53 & 22.93 & 31.07 & 26.94 \\
\hline$\% G^{*} E \mathrm{SS}$ due to IPCA3 & & 15.50 & 7.55 & 11.51 & 10.27 & 10.13 & 8.32 \\
\hline$\% G^{*} E \mathrm{SS}$ due to IPCA4 & & 6.00 & 3.84 & 5.40 & 8.75 & 7.04 & 8.17 \\
\hline$\% G^{*} E$ SS due to IPCA5 & & 3.64 & 2.75 & 3.57 & 5.24 & 4.88 & 6.64 \\
\hline
\end{tabular}

higher mean and \% SS due to IPCA1 and IPCA2 were observed at 6 MAP in comparison to at 3 and $9 \mathrm{MAP}$. This indicated that there were fewer interactions, therefore, more stable symptoms expression at 6 MAP.

ASV ranked the genotypes based on the least scores where low scores represented the most stable genotypes. Low ASV coupled with low disease severity resulted 
in the selection of stable genotypes with minimal CMD symptoms. All the genotypes had low CMD severity of $\leq 1.8$ (Table S1). Based on CMD foliar symptoms at $6 \mathrm{MAP}$, the most stable genotypes with regards to low ASV values and their position relative to the biplot origin (0.0) were Albert, NDL 2003/111, KBH 2002/66 and NDL 2003/31 with a means $\leq 1.27$ (Figure 1, Table S1). The GSI ranking combines both stability and higher scores of a trait. Accordingly, site Chambezi's environments had moderate stability with the highest mean CMD
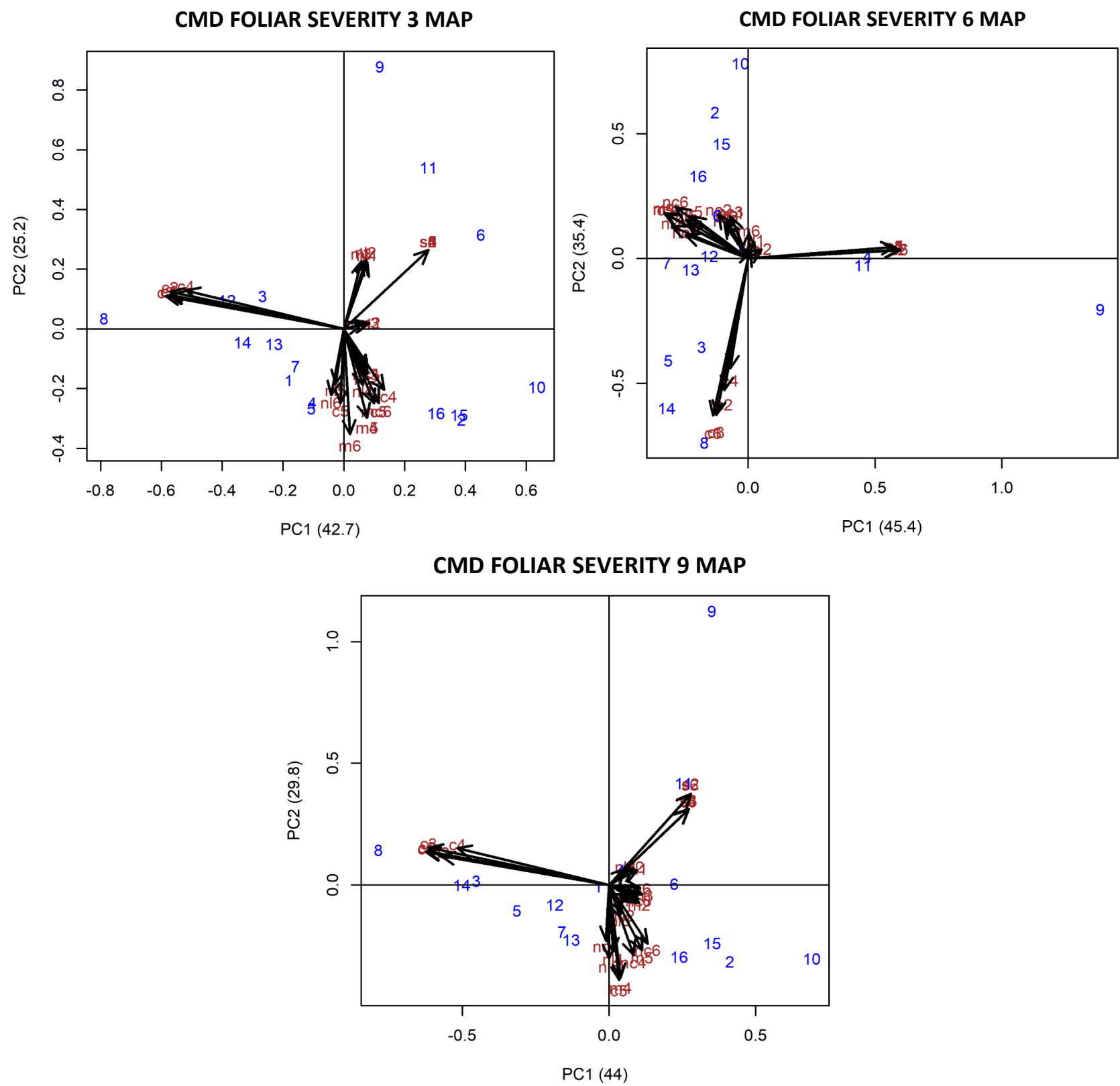

Figure 1. AMM2 biplot for CMD foliar symptoms. Environments. Chambezi 2013-2018 (c - c6), Nachingwea $2013-2018$ (nc1 nc6), Mtopwa 2013-2018 (m1 - m6), Naliendele 2013-2018 (nl - nl6), Segera 2013-2018 (s1 - s6). Genotypes: Albert (1), KBH 2002/26 (2), KBH 2002/477 (3), KBH 2002/482 (4), KBH 2002/494 (5), KBH 2002/66 (6), KBH 96/1056 (7), Kiroba (8), Mahiza (9), Mkumba (10), Naliendele 134 (11), NDL 2003/111 (12), NDL 2003/31 (13), NDL 2005/1471 (14), NDL 2005/1472 (15), Pwani (16). 
foliar severity of 1.24 (Figure 2, Table S1).

\subsection{CBSD Foliar Symptoms}

There was a highly significant $(\mathrm{P} \leq 0.001)$ effect of genotype, environment and $G^{*} E$ interaction for CBSD foliar symptoms at 3, 6, and 9 MAP (Table 3). Percent SS due to genotype $(60.90 \%-69.14 \%)$ was higher than due to environment
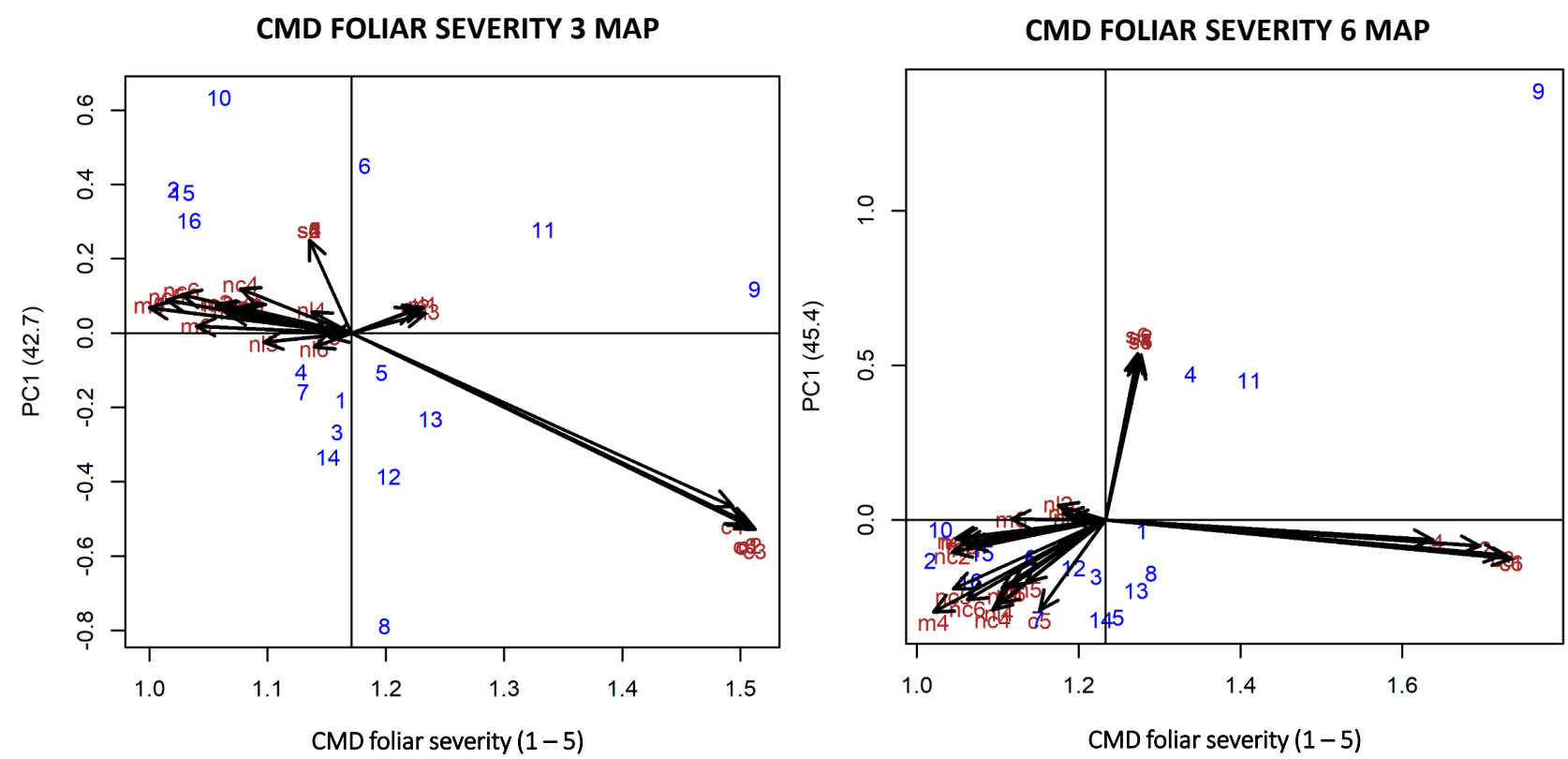

CMD FOLIAR SEVERITY 9 MAP

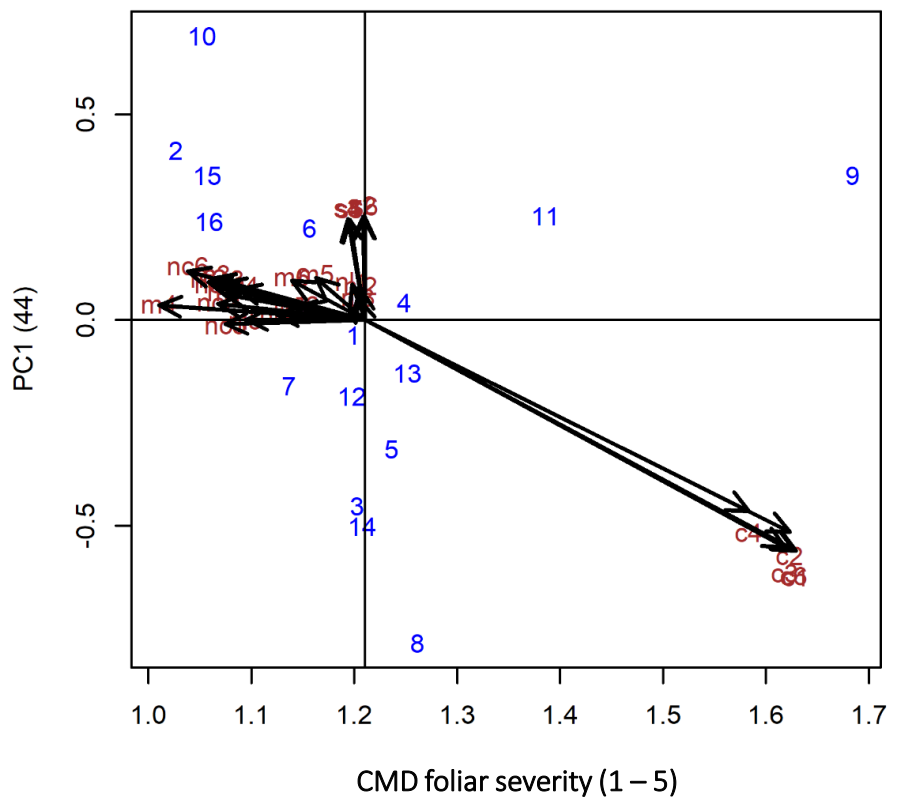

Figure 2. AMM1 biplot for CMD foliar symptoms. Environments. Chambezi 2013-2018 (c - c6), Nachingwea $2013-2018$ (nc1 nc6), Mtopwa 2013-2018 (m1 - m6), Naliendele 2013-2018 (nl - nl6), Segera 2013-2018 (s1 - s6). Genotypes: Albert (1), KBH 2002/26 (2), KBH 2002/477 (3), KBH 2002/482 (4), KBH 2002/494 (5), KBH 2002/66 (6), KBH 96/1056 (7), Kiroba (8), Mahiza (9), Mkumba (10), Naliendele 134 (11), NDL 2003/111 (12), NDL 2003/31 (13), NDL 2005/1471 (14), NDL 2005/1472 (15), Pwani (16). 
$(4.18 \%-6.25 \%)$ and $G^{*} E(29.84 \%$ - 34.91\%) indicating that most of the variations observed were due to genetic make-up. Four IPCAs were significant $(\mathrm{P} \leq$ $0.05)$ for CBSD 3 and 9 MAP while 6 MAP had three significant IPCAs. IPCA1 and IPCA2 accounted for a total SS of $64.69 \%, 72.42 \%$ and $63.83 \%$ of the $G^{*} E$ variation for CBSD 3, 6 and 9 MAP, respectively. The mean CBSD foliar severity was $1.46,1.61$ and 1.57 at 3,6, and 9 MAP. Similar to CMD symptoms, a higher mean and \% SS due to IPCA1 and IPCA2 were observed at 6 MAP, indicating more stable symptoms expression at this time point.

Based on foliar symptoms at 6 MAP, all the genotypes had low CBSD foliar severity $\leq 1.7$ apart from Naliendele 134, Mkumba, Mahiza and Albert. The most stable genotypes with low ASV included KBH 2002/66, NDL 2005/1471, KBH 96/1056 and NDL 2003/111 with mean of $\leq 1.27$ (Figure 3, Table S2). Although Mahiza too had a low ASV of 0.49 , it had a higher severity of 2.27. Similar to CMD symptoms, site Chambezi's environments had the highest mean CBSD foliar severity of 1.77 with moderate GSI ranking indicating moderate stability (Figure 4, Table S2).

\subsection{CBSD Root Necrosis}

The effect of genotype, environment and $G^{*} E$ interaction was highly significant $(\mathrm{P} \leq 0.001)$ for root necrosis (Table 4$)$. Percent SS due to genotype was highest at $52.14 \%$ followed by $G^{*} E(35.19 \%)$ and environment $(12.66 \%)$. The findings indicated that genetic make-up greatly influenced the expression of root symptoms. Five IPCAs had significant $(\mathrm{P} \leq 0.05)$ mean squares and IPCA1 and IPCA2 accounted for a total SS of $60.51 \%$ of the $G^{*} E$ variation. The most stable genotypes with low ASV included NDL 2003/11, Pwani, NDL 2005/1471, KBH 2002/482 and NDL 2003/31 (0.42) with a mean of $\leq 1.72$ (Figure 5, Table S3). All the genotypes had low root necrosis severity $(\leq 1.9)$ below the grand mean

CBSD FOLIAR SEVERITY 3 MAP

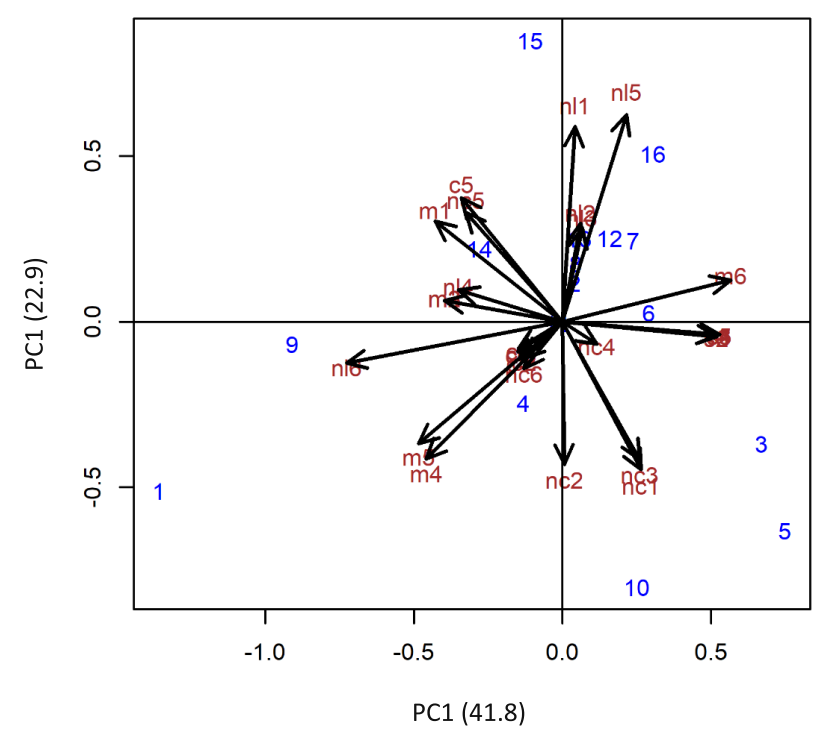

CBSD FOLIAR SEVERITY 6 MAP

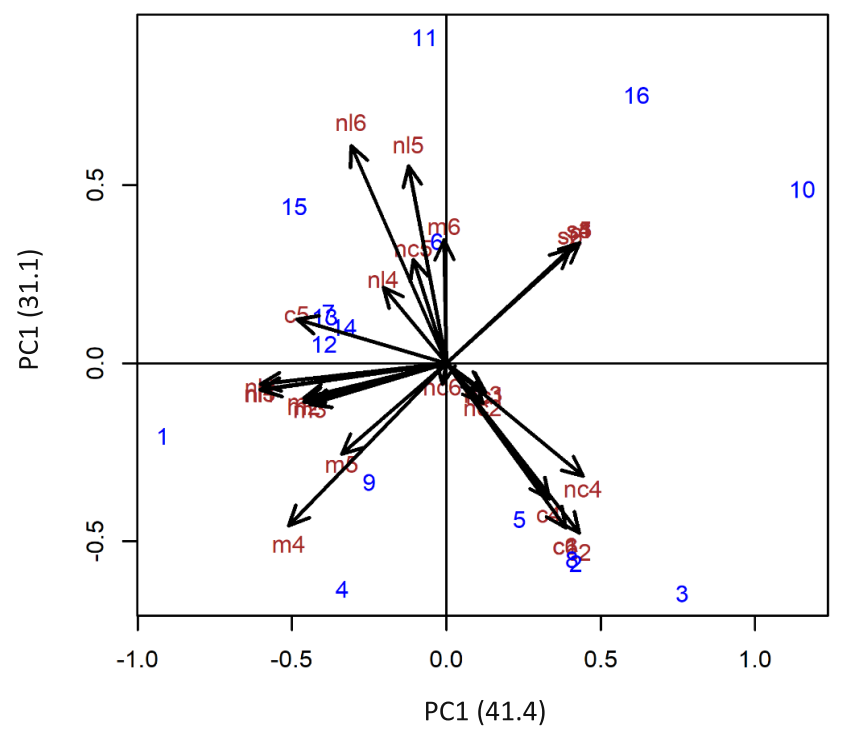




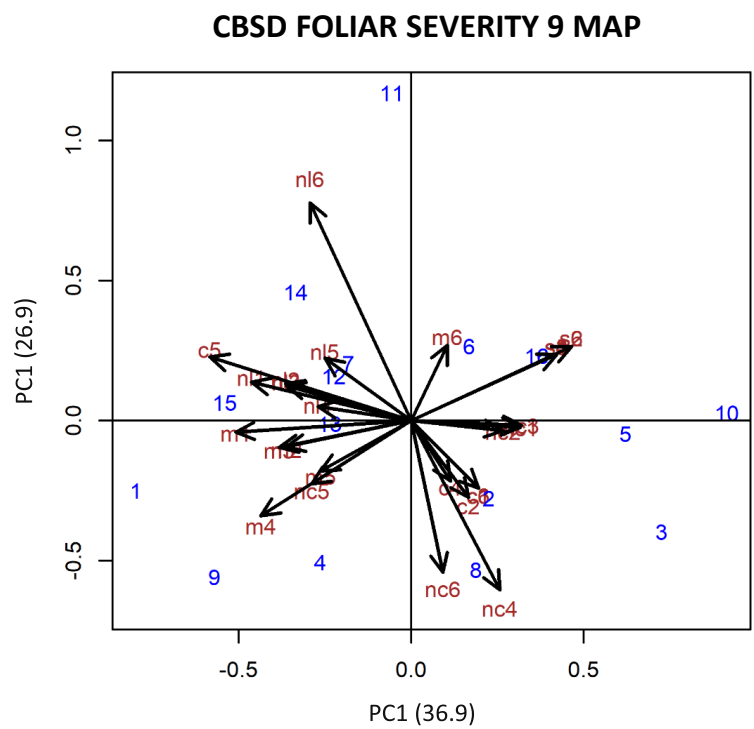

Figure 3. AMMI2 biplot for CBSD foliar symptoms. Environments. Chambezi 2013-2018 (c - c6), Nachingwea 2013-2018 (nc1 - nc6), Mtopwa 2013-2018 (m1 - m6), Naliendele 2013-2018 (nl - nl6), Segera 2013-2018 (s1 - s6). Genotypes: Albert (1), KBH 2002/26 (2), KBH 2002/477 (3), KBH 2002/482 (4), KBH 2002/494 (5), KBH 2002/66 (6), KBH 96/1056 (7), Kiroba (8), Mahiza (9), Mkumba (10), Naliendele 134 (11), NDL 2003/111 (12), NDL 2003/31 (13), NDL 2005/1471 (14), NDL 2005/1472 (15), Pwani (16).

Table 4. Combined AMMI ANOVA for root necrosis, root weight and dry matter of 16 cassava genotypes evaluated across 30 environments ( 6 planting seasons $\times 5$ sites).

\begin{tabular}{|c|c|c|c|c|}
\hline \multirow{2}{*}{ Source } & \multirow{2}{*}{$\mathrm{df}$} & \multicolumn{3}{|c|}{ Mean squares } \\
\hline & & Root necrosis & Root weight & Dry matter \\
\hline Treatment & 479 & $3.60^{* * *}$ & $1778.05^{\star * *}$ & $159.99^{* *}$ \\
\hline Genotype $(G)$ & 15 & $59.97^{\star * *}$ & $10,009.40^{\star * *}$ & $33.38^{*}$ \\
\hline Environment $(E)$ & 29 & $7.53^{* * *}$ & $12,572.60^{* * *}$ & $2252.12^{* * *}$ \\
\hline Block & 60 & $0.95^{\star *}$ & $1220.80^{\star * *}$ & $67.46^{* * *}$ \\
\hline Interaction $\left(G^{*} E\right)$ & 435 & $1.40^{* * *}$ & $774.60^{* * *}$ & $24.88^{* * *}$ \\
\hline IPCA1 & 43 & $4.90^{* * *}$ & $2830.10^{\star * *}$ & $94.28^{\star * \star}$ \\
\hline IPCA2 & 41 & $3.82^{* * *}$ & $2010.01^{\star * *}$ & $73.80^{\star \star \star}$ \\
\hline IPCA3 & 39 & $1.41^{* * *}$ & $886.32^{\star * *}$ & $34.06^{* * *}$ \\
\hline IPCA4 & 37 & $1.17^{* * *}$ & $722.53^{\star * *}$ & $17.55^{\star * *}$ \\
\hline IPCA5 & 35 & $1.15^{\star}$ & $507.32^{\star * *}$ & 14.20 \\
\hline \multirow[t]{2}{*}{ Error } & 899 & 0.56 & 251.5 & 19.31 \\
\hline & & \multicolumn{3}{|c|}{ Sum of squares } \\
\hline Treatment & 479 & 1725.14 & $851,688.00$ & $76,633.00$ \\
\hline Genotype $(G)$ & 15 & 899.54 & $150,149.00$ & 501.00 \\
\hline Environment $(E)$ & 29 & 218.45 & $364,607.00$ & $65,311.00$ \\
\hline Block & 60 & 56.87 & $73,249.00$ & 4048.00 \\
\hline Interaction $\left(G^{*} E\right)$ & 435 & 607.15 & $336,932.00$ & $10,821.00$ \\
\hline IPCA1 & 43 & 210.79 & $121,694.39$ & 4054.13 \\
\hline IPCA2 & 41 & 156.57 & $82,410.25$ & 3025.58 \\
\hline IPCA3 & 39 & 54.81 & $34,566.54$ & 1328.29 \\
\hline IPCA4 & 37 & 43.13 & $26,733.41$ & 649.33 \\
\hline IPCA5 & 35 & 40.39 & $17,756.27$ & 497.10 \\
\hline
\end{tabular}




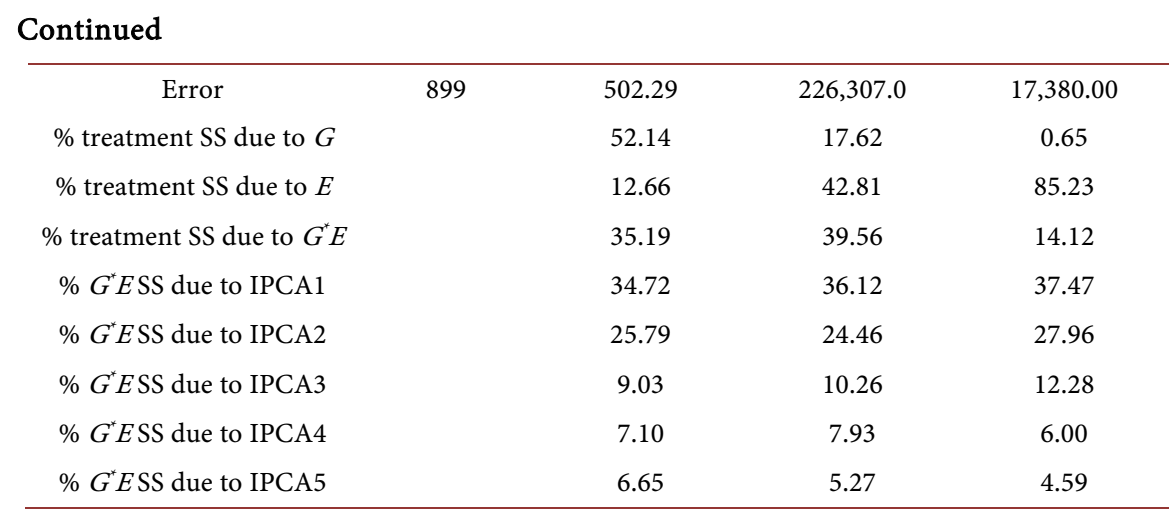

CBSD FOLIAR SEVERITY 3 MAP

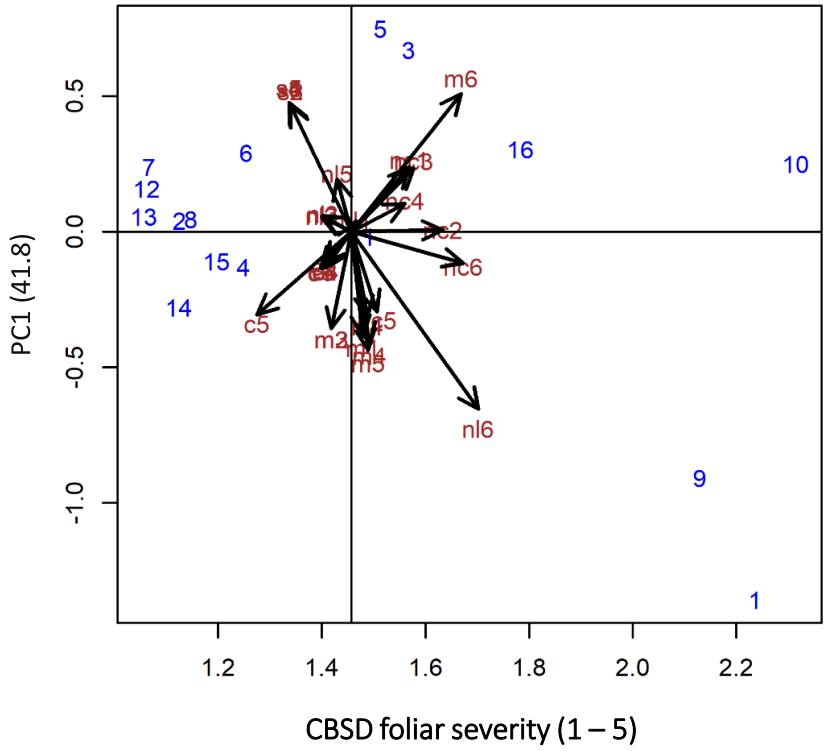

CBSD FOLIAR SEVERITY 6 MAP

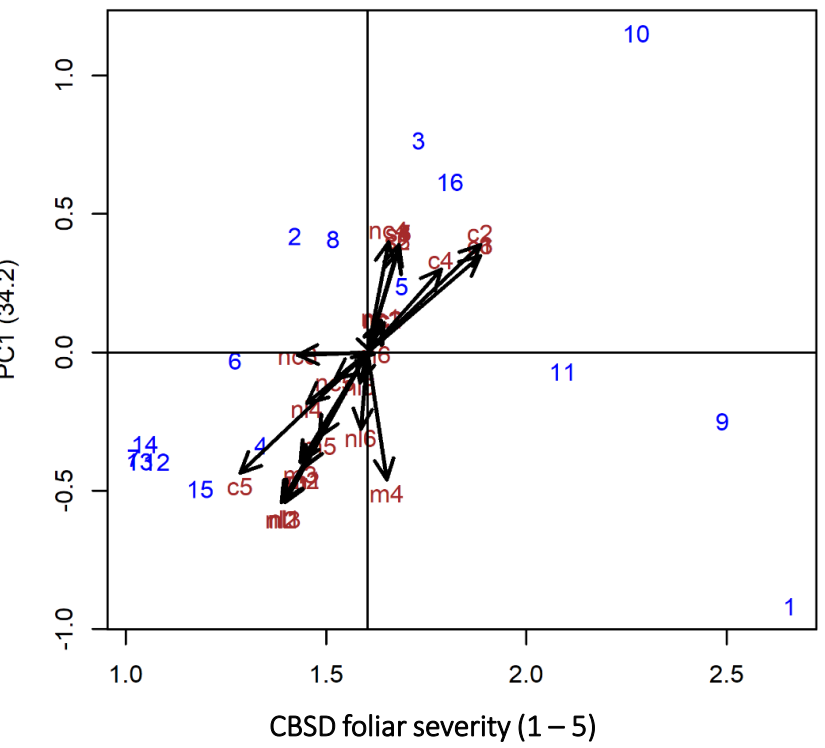

CBSD FOLIAR SEVERITY 9 MAP

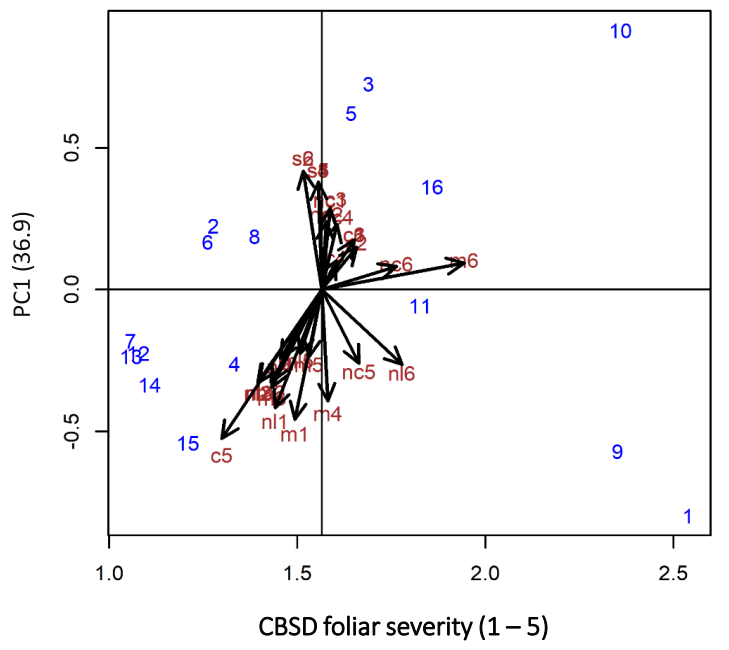

Figure 4. AMM2 biplot for CBSD foliar symptoms. Environments. Chambezi 2013-2018 (c - c6), Nachingwea $2013-2018$ (nc1 - nc6), Mtopwa 2013-2018 (m1 - m6), Naliendele 2013-2018 (nl - nl6), Segera 2013-2018 (s1 - s6). Genotypes: Albert (1), KBH 2002/26 (2), KBH 2002/477 (3), KBH 2002/482 (4), KBH 2002/494 (5), KBH 2002/66 (6), KBH 96/1056 (7), Kiroba (8), Mahiza (9), Mkumba (10), Naliendele 134 (11), NDL 2003/111 (12), NDL 2003/31 (13), NDL 2005/1471 (14), NDL 2005/1472 (15), Pwani (16). 
of 2.29 apart from Mkumba (2.29), Naliendele (3.52). Mahiza (3.08), KBH 2002/477 (2.22) and KBH 2002/66 (2.04). The genotypes with the highest root necrosis severity also had high ASV, therefore, unstable. Among the environments, Chambezi 2013 to 2018 has the highest mean root necrosis severity of 2.33 with moderate GSI ranking indicating moderate stability (Figure 6, Table S3).

\subsection{Root Weight}

The effect of genotype, environment and $G^{*} E$ interaction was highly significant
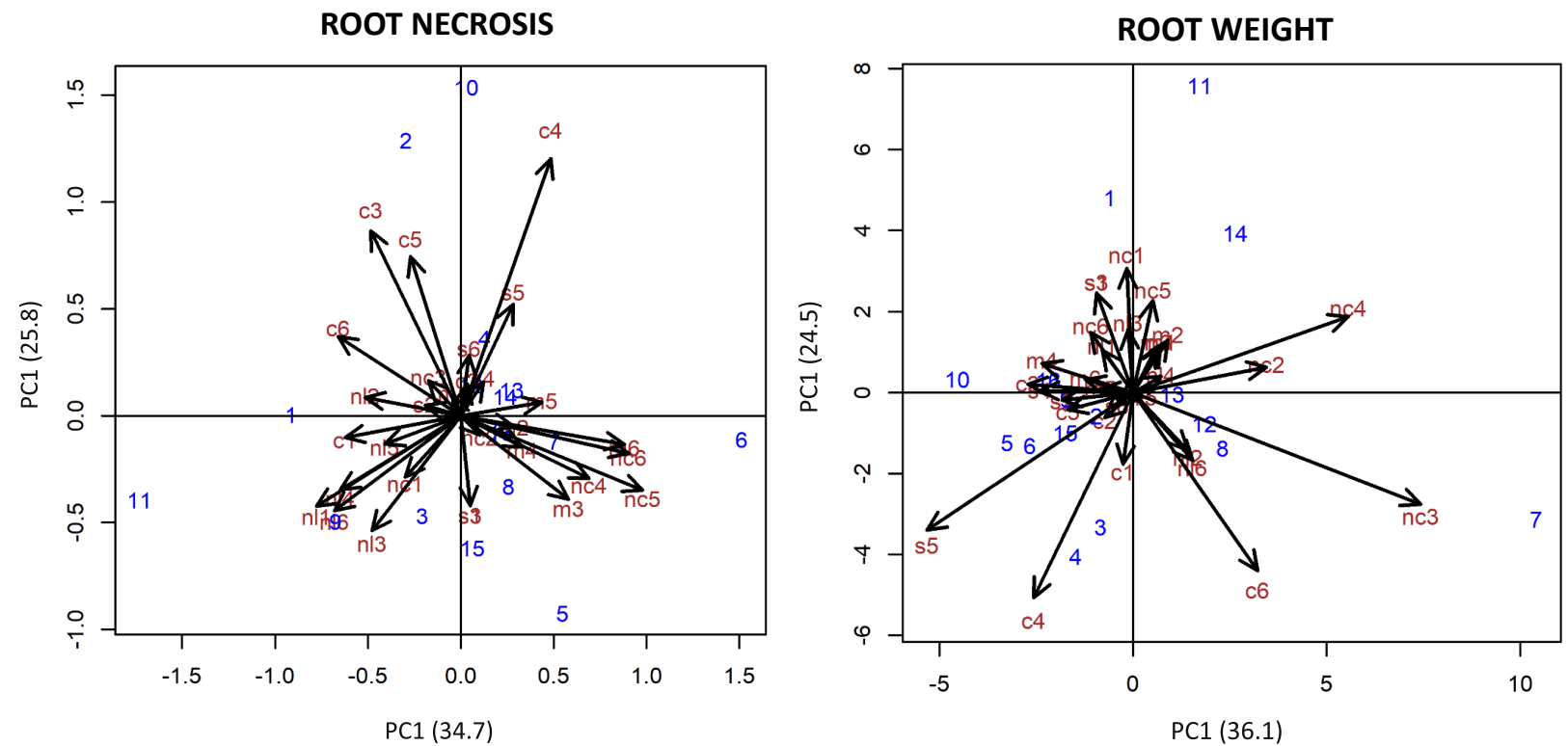

\section{DRY MATTER CONTENT}

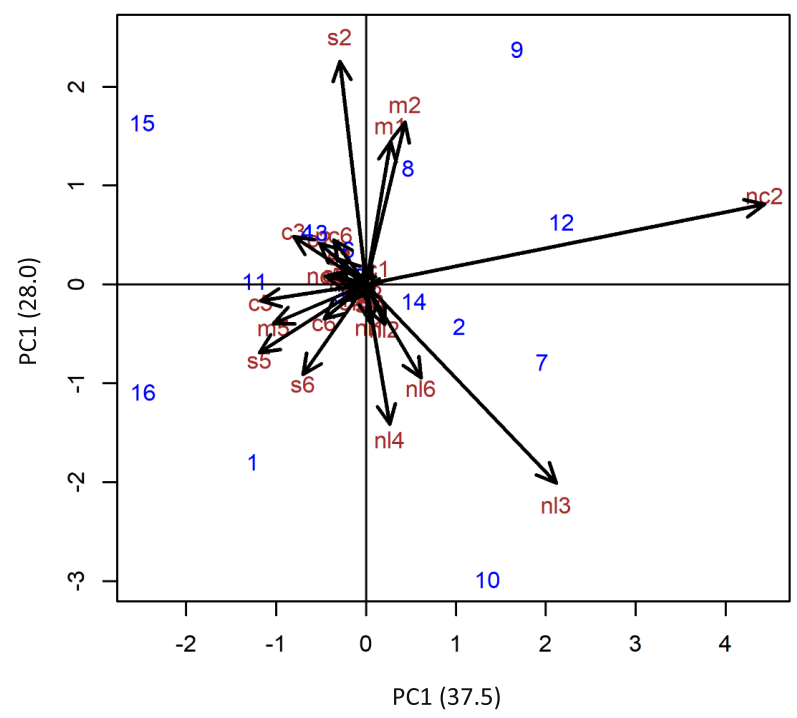

Figure 5. AMM2 biplot for root necrosis, root weight and dry matter content. Environments. Chambezi 2013-2018 (c - c6), Nachingwea 2013-2018 (nc1 - nc6), Mtopwa 2013-2018 (m1 - m6), Naliendele 2013-2018 (nl - nl6), Segera 2013-2018 (s1 - s6). Genotypes: Albert (1), KBH 2002/26 (2), KBH 2002/477 (3), KBH 2002/482 (4), KBH 2002/494 (5), KBH 2002/66 (6), KBH 96/1056 (7), Kiroba (8), Mahiza (9), Mkumba (10), Naliendele 134 (11), NDL 2003/111 (12), NDL 2003/31 (13), NDL 2005/1471 (14), NDL 2005/1472 (15), Pwani (16). 
ROOT NECROSIS

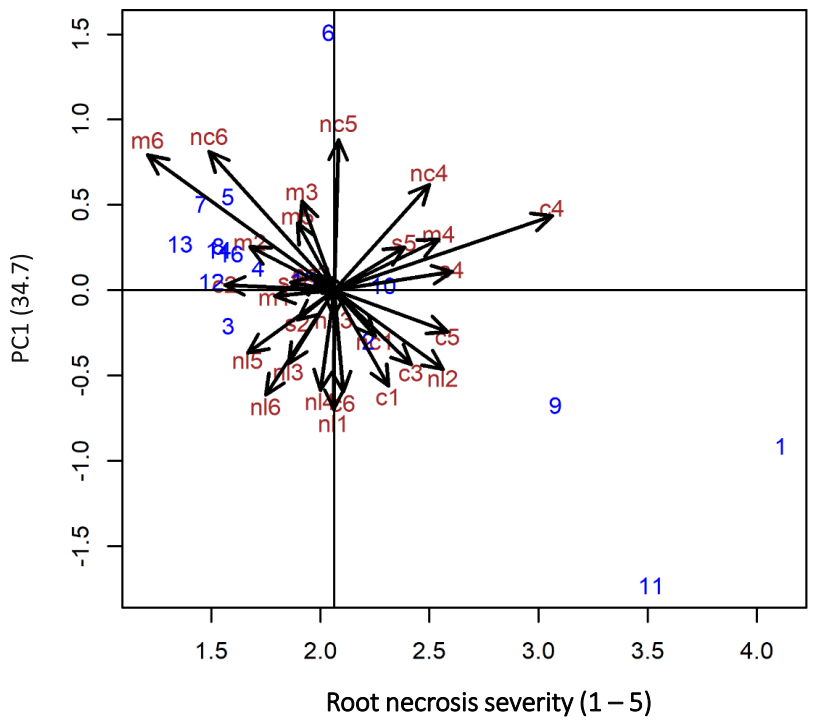

ROOT WEIGHT

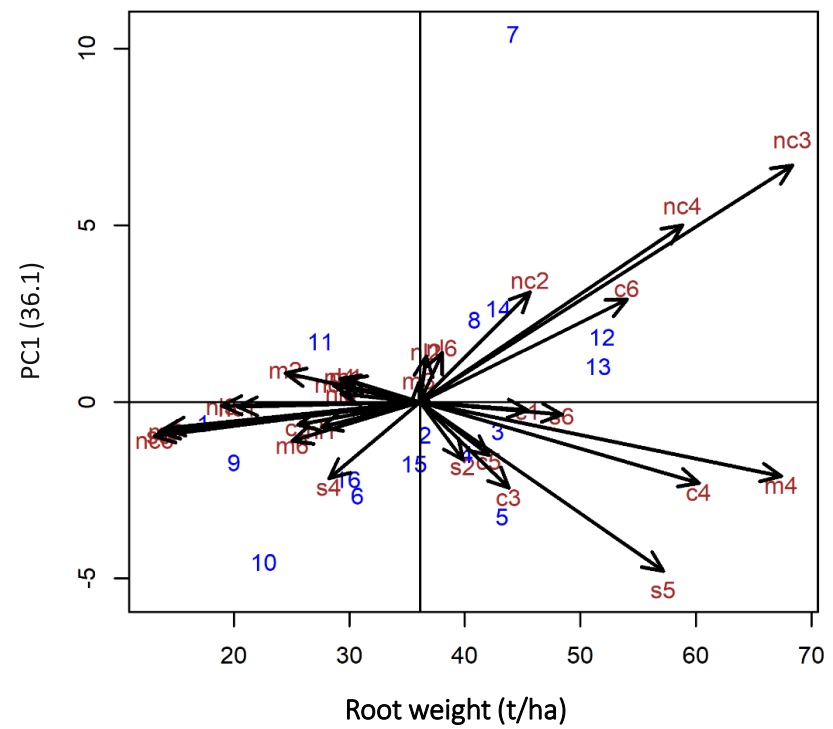

DRY MATTER CONTENT

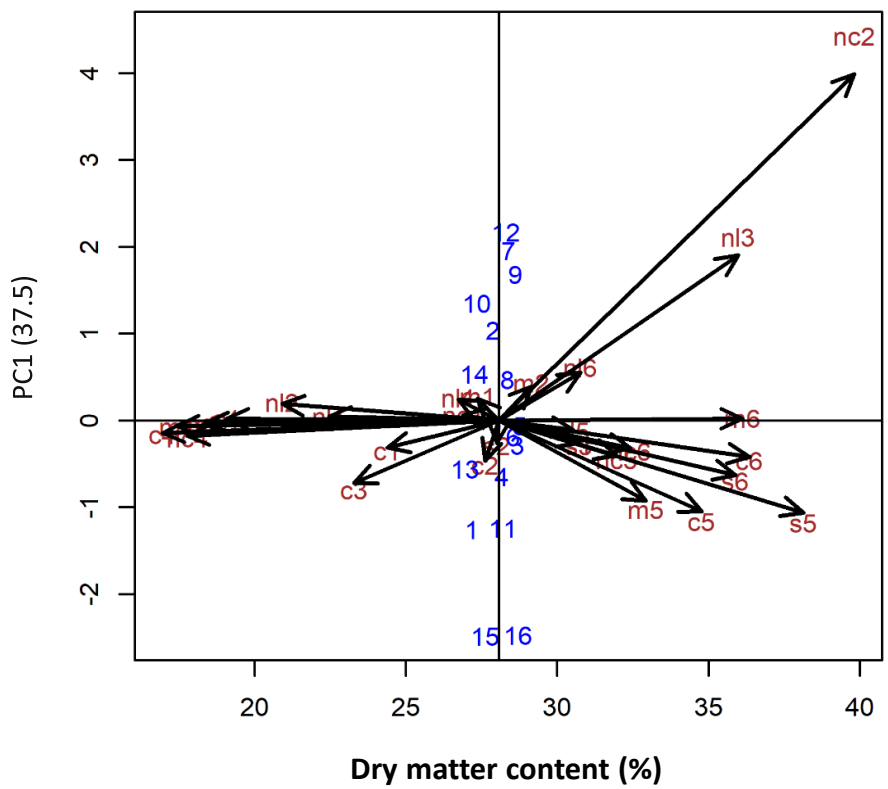

Figure 6. AMM1 biplot for root necrosis, root weight and dry matter content. Environments. Chambezi 2013-2018 (c - c6), Nachingwea 2013-2018 (nc1 - nc6), Mtopwa 2013-2018 (m1 - m6), Naliendele 2013-2018 (nl - nl6), Segera 2013-2018 (s1 - s6). Genotypes: Albert (1), KBH 2002/26 (2), KBH 2002/477 (3), KBH 2002/482 (4), KBH 2002/494 (5), KBH 2002/66 (6), KBH 96/1056 (7), Kiroba (8), Mahiza (9), Mkumba (10), Naliendele 134 (11), NDL 2003/111 (12), NDL 2003/31 (13), NDL 2005/1471 (14), NDL 2005/1472 (15), Pwani (16).

( $\mathrm{P} \leq 0.001)$ for root weight (Table 4). Percent SS due to environment was highest at $42.81 \%$ followed closely by $G^{*} E(35.19 \%)$ and genotype (17.62\%). The findings indicated that both the environment and $G^{*} E$ greatly influenced the expression of root weight. Five IPCAs had significant $(\mathrm{P} \leq 0.05)$ mean squares and IPCA1 and IPCA2 accounted for a total SS of $60.58 \%$ of the $G^{*} E$ variation. The most stable genotypes with low ASV included KBH 2002/477, NDL 2003/31, Mahiza and NDL 2005/477 (Figure 5, Table S3). Since ASV measure alone is 
not sufficient for the selection of superior genotypes, GSI ranking was used as it combines both genotype stability and high yield. Accordingly, the most stable and high yielding genotypes included NDL 2003/31 (51.55 t/ha), NDL 2003/111 (51.86 t/ha), KBH 2002/477 (42.86 t/ha) and NDL 2005/1472 (35.59 t/ha) (Table S3). Chambezi 2013 to 2018 environments had the highest mean root weight (45.21 t/ha) with moderate to high stability based on GSI ranking (Figure 6, Table S3). Higher yields were observed in favourable environments for example Chambezi which had higher rainfall than other sites (Figure 7, Table 1, Table S3). Site Segera having received the least rainfall was one of the sites with a lower combined mean root weight of $33.47 \mathrm{t} / \mathrm{ha}$.

\subsection{Dry Matter Content}

The effect of genotype, environment and $G^{*} E$ interaction was significant $(\mathrm{P} \leq$

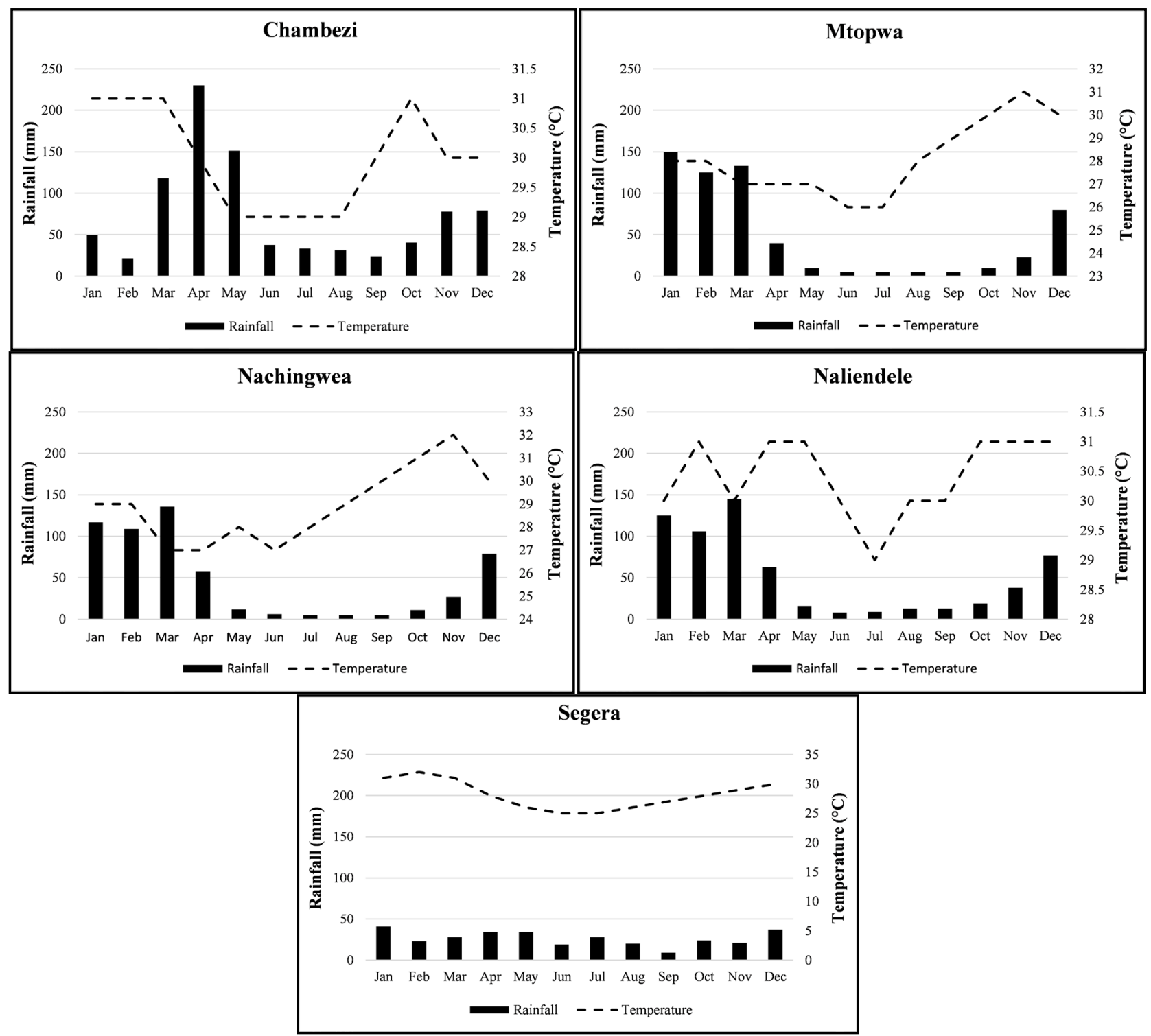

Figure 7. Mean monthly rainfall and temperature for the five sites from 2013 to 2018. 
0.001 ) for dry matter content (Table 4). Percent SS due to environment was very high at $85.23 \%$ followed by $G^{*} E(14.12 \%)$ and very low SS due to genotype $(0.68 \%)$. Four IPCAs had significant $(\mathrm{P} \leq 0.05)$ mean squares and IPCA1 and IPCA2 accounted for a total SS of $65.43 \%$ of the $G^{*} E$ variation. The mean dry matter contents for genotypes were close ranging from 26.95\% - 28.77\% (Figure 6, Table S3). The genotypes with high stability and dry matter content included $\mathrm{KBH}$ 2002/494 (28.77\%), KBH 2002/477 (28.69\%), KBH 2002/66 (28.55\%) Kiroba (28.37\%) and KBH 2002/482 (28.18\%) (Figure 5, Table S3). Segera which received the least rainfall had the highest combined mean dry matter content of $30.43 \%$. Root necrosis may have affected dry matter content since environments with higher root necrosis had corresponding low dry matter content and vice versa. For example, among the environments in Chambezi, Chambezi 2016 had the highest root necrosis severity (3.06) and the lowest dry matter content (16.96\%). Similar observations were made in other sites.

\section{Discussion}

The performance of cassava is subject to the strong influence of genotype, environment and $G^{*} E$ interactions [15] [29] [47]. TARI-Naliendele has been developing improved genotypes, however, only a few varieties have been released. The newly developed breeding lines are in their final stages of breeding. Therefore, evaluating them in diverse environments and providing recommendations for suitable ones will contribute to increasing cassava production and improved food and nutrition security.

The AMMI model was used in this study and the effects of genotype, environment, and $G^{*} E$ interactions were significant. Percent SS due to environment was the highest followed by $G^{*} E$ interaction in CMD foliar symptoms severity, root weight and dry matter content showing that environment and $G^{*} E$ interaction greatly influenced the variations observed. On the other hand, \% SS due to genotype was the highest followed by $G^{*} E$ interaction in CBSD foliar symptoms and root necrosis. A considerable percentage of $G^{*} E$ interaction was explained by IPCA1 (34.725\% - 45.20\%), followed by IPCA2 (22.93\% - 35.31\%) and lastly IPCA3 (7.55\% - 15.50\%). Several studies have shown similar findings where a significant and greater percentage of $G^{*} E$ interaction was explained by IPCA1 and IPCA2 [15] [29] [47] [48].

Mean CMD and CBSD foliar symptoms severity increased from 3 to 6 MAP then dropped at 9 MAP. The total \% SS due to both IPCA1 and IPCA2 was the highest at $6 \mathrm{MAP}$ for both $\mathrm{CMD}$ and CBSD. A possible explanation for this is that at 3 MAP, some plants may still have low viral titre [49] and may not express symptoms thus causing significant variations in the replications and environments. This may result in the representation of substantial \% SS by other IPCAs apart from IPCA 1 and 2. CBSD foliar symptoms are more difficult to recognize in older plants as the lower leaves with prominent symptoms senesce and fall off, causing variation in symptoms expression among the plants partic- 
ularly at 9 MAP [50]. Additionally, younger leaves are more susceptible to CMD resulting in a decrease in CMD symptoms in some plants with increasing plant age [51]. In our earlier study we reported a higher heritability at 6 MAP for CMD and CBSD foliar symptoms thus emphasising the importance of assessment at this time point [20].

Stability analysis methods are often used by breeders to identify genotypes that have stable performance and respond positively to improvements in environmental conditions [39] [40]. With regards to CMD and CBSD, suitable genotypes would have low ASV and low disease severity. Further, genotypes with CMD foliar severity scores $(<2.0)$ are classified as resistant while those with $(\geq 2.0)$ as susceptible [52]. In this study, all genotypes had low foliar severity $(>1.35)$ apart from Mahiza which was slightly higher at 1.77 . The most stable genotypes with low CMD foliar severity $(\leq 1.28)$ were Albert, NDL 2003/111, KBH 2002/66, KBH 2002/26, NDL 2005/1472, NDL 2003/31 and KBH 96/1056.

CBSD-resistant varieties exhibit minimal symptoms with a severity of $(<2.0)$ both on leaves and roots, tolerant once have more severe symptoms on leaves $(\geq 2.0)$ coupled with minimal symptoms on roots $(<2.0)$ while susceptible ones developed severe symptoms on both leaves and roots (>2.0) [16] [53] [54]. All genotypes apart from Naliendele 134, Mkumba, Mahiza, Albert, KBH 2002/26 and KBH 2002/66 had minimal symptoms $(<2.0)$ both on leaves and roots. Stable genotypes with low ASV on CBSD foliar severity did not necessarily have stable root necrosis severity. This could be due to the different QTLs affecting CBSD foliar symptoms and root necrosis leading to varied expression of symptoms on leaves and roots [53]. Stable resistant genotypes with minimal symptoms on both leaves and roots (<2.0) were NDL 2005/1471 NDL 2003/111, KBH 2002/482 and NDL 2003/31. The environments in site Chambezi had the highest combined means for CMD (1.24), CBSD (1.77), and root necrosis (2.06). Masumba et al. [53] reported higher CMD and CBSD severity suggesting the suitability of this site for disease resistance evaluation. The environments, however, had higher GSI ranking portraying moderate stability. Virus transmission and disease spread are determined by inoculum pressure and their variation from season to season may have contributed to the lower stability observed [55].

Based on GSI ranking, the most stable high yielding genotypes included NDL 2003/31 (51.55 t/ha), NDL 2003/111 (51.86 t/ha), KBH 2002/477 (42.86 t/ha) and NDL 2005/1472 (35.59 t/ha). Higher yields were recorded in favourable environments indicating that genotypes can exploit their full potential to yield well under good environmental conditions. Accordingly, the environments in site Chambezi had the highest combined root weight means of $45.21 \mathrm{t} / \mathrm{ha}$. Chambezi had higher rainfall particularly during the first six months, a critical period for root initiation and development [56] [57]. Most of the genotypes had moderately high dry matter content ranging from $26.95 \%-28.77 \%$. Low rainfall results in high dry matter content as was observed in the environments in site Segera which had the highest combined dry matter content mean of 30.43 [16] [58]. 
Additionally, the environments with the least CBSD root necrosis symptoms had the highest dry matter content and vice versa, indicating that presence of root symptoms can affect key agronomic traits leading to loss of farmer preferred traits [16] [58].

\section{Conclusion}

$G^{*} E$ was significant $(\mathrm{P} \leq 0.05)$ for CMD foliar symptoms, CBSD foliar and root symptoms, root weight and dry matter content. This emphasised the importance of testing genotypes in multiple environments before an effective selection is made. Besides, variations were also significant among the test environments. Site Chambezi had the highest mean CMD and CBSD severity; therefore, it has been empirically confirmed as the most suitable environment for evaluation for disease resistance. Cassava produces high yield under favourable conditions such as adequate rainfall and soil fertility as was observed in Chambezi. The most stable genotypes which combined CMD and CBSD resistance, high yield were NDL 2003/31 and NDL 2003/111. These genotypes outperformed the checks Albert, Kiroba, Pwani, Mahiza, Mkumba and Naliendele 134 indicating that they have the potential to increase cassava productivity and should therefore be recommended for release to cassava farmers or further breeding prospects.

\section{Acknowledgements}

This work was carried out from contributions from two donors; the African Union Commission (AUC) under the grant numbers AURG/2/141 and AURG II-1060-2016, and the European Union Commission with the grant number DCIFOOD-2012/290-635.

\section{Conflicts of Interest}

The authors declare no conflicts of interest regarding the publication of this paper.

\section{References}

[1] FAOSTAT (Food and Agriculture Organization Corporate Statistical Database) (2019) Food and Agriculture Organization of the United Nations STAT.

http://www.fao.org/faostat/en/\#data/QC/2018

[2] Jarvis, A., Ramirez-Villegas, J., Campo, B.V.H. and Navarro-Racines, C. (2012) Is Cassava the Answer to African Climate Change Adaptation? Tropical Plant Biology, 5, 9-29. https://doi.org/10.1007/s12042-012-9096-7

[3] Nassar, N.M.A. and Ortiz, R. (2007) Cassava Improvement: Challenges and Impacts. Journal of Agricultural Science, 145, 163-171. https://doi.org/10.1017/S0021859606006575

[4] Anyanwu, C.N., Beto, C.N., Ezeoha, S.L. and Ogbuagu, N.J. (2015) Sustainability of Cassava (Manihot esculenta Crantz) as Industrial Feedstock, Energy and Food Crop in Nigeria. Renewable Energy, 81, 745-752. https://doi.org/10.1016/j.renene.2015.03.075

[5] Bhuiyan, M.M. and Iji, P.A. (2015) Energy Value of Cassava Products in Broiler 
Chicken Diets with or without Enzyme Supplementation. Asian-Australasian Journal of Animal Sciences, 28, 1317-1326. https://doi.org/10.5713/ajas.14.0915

[6] Tonukari, N., Ezedom, T., Enuma, C.C., Sakpa, S.O., Awioroko, O.J., Eraga, L. and Odiyoma, E. (2015) White Gold: Cassava as an Industrial Base. American Journal of Plant Sciences, 6, 972-979. https://doi.org/10.4236/ajps.2015.67103

[7] Sriroth, K., Piyachomkwan, K., Wanlapatit, S. and Nivitchanyong, S. (2010) The Promise of a Technology Revolution in Cassava Bioethanol: From Thai Practice to the World Practice. Fuel, 89, 1333-1338. https://doi.org/10.1016/j.fuel.2009.12.008

[8] Fermont, A.M., Van Asten, P.J., Tittonell, P., Van Wijk, M.T. and Giller, K.E. (2009) Closing the Cassava Yield Gap: An Analysis from Smallholder Farms in East Africa. Field Crops Research, 112, 24-36. https://doi.org/10.1016/j.fcr.2009.01.009

[9] Samura, A.E., Lakoh, K.A., Nabay, O., Fomba, S.N. and Koroma, J.P. (2017) Effect of Cassava Mosaic Disease (CMD) on Yield and Profitability of Cassava and Gari Production Enterprises in Sierra Leone. Journal of Agricultural Science, 9, 205-216. https://doi.org/10.5539/jas.v9n2p205

[10] Patil, B.L., Legg, J.P., Kanju, E. and Fauquet, C.M. (2015) Cassava Brown Streak Disease: A Threat to Food Security in Africa. Journal of General Virology, 96, 956-968. https://doi.org/10.1099/jgv.0.000014

[11] Legg, J.P., Jeremiah, S.C., Obiero, H.M., Maruthi, M.N., Ndyetabula, I., Okao-Okuja, G., Bouwmeester, H., Bigirimana, S., Tata-Hangy, W., Gashaka, G., Mkamilo, G. and Lava Kumar, P. (2011) Comparing the Regional Epidemiology of the Cassava Mosaic and Cassava Brown Streak Virus Pandemics in Africa. Virus Research, 159, 161-170. https://doi.org/10.1016/j.virusres.2011.04.018

[12] Tembo, M., Mataa, M., Legg, J., Chikoti, P.C. and Ntawuruhunga, P. (2017) Cassava Mosaic Disease: Incidence and Yield Performance of Cassava Cultivars in Zambia. Journal of Plant Patholology, 99, 681-689.

[13] Masinde, E.A., Ogendo, J., Mkamilo, G., Maruthi, M.N., Hillocks, R., Mulwa, R.M.S. and Arama, P.F. (2016) Occurrence and Estimated Losses Caused by Cassava Viruses in Migori County, Kenya. African Journal of Agricultural Research, 11, 20642074. https://doi.org/10.5897/AJAR2016.10786

[14] Mohammed, I.U., Ghosh, S. and Maruthi, M.N. (2015) Host and Virus Effects on Reversion in Cassava Affected by Cassava Brown Streak Disease. Plant Pathology, 65, 593-600. https://doi.org/10.1111/ppa.12458

[15] Jiwuba, L., Danquah, A., Asante, I., Blay, E., Onyeka, J., Danquah, E. and Egesi, C. (2020) Genotype by Environment Interaction on Resistance to Cassava Green Mite Associated Traits and Effects on Yield Performance of Cassava Genotypes in Nigeria. Frontiers in Plant Science, 11, Article ID: 572200. https://doi.org/10.3389/fpls.2020.572200

[16] Masinde, E.A., Mkamilo, G., Ogendo, J., Hillocks, R., Mulwa, R.M.S., Kimata, B. and Maruthi, M.N. (2017) Genotype by Environment Interactions in Identifying Cassava (Manihot Esculenta Crantz) Resistant to Cassava Brown Streak Disease. Field Crops Research, 215, 39-48. https://doi.org/10.1016/j.fcr.2017.10.001

[17] Maroya, N.G., Kulakow, P., Dixon, A.G.O. and Maziya-Dixon, B.B. (2012) Genotype $\times$ Environment Interaction of Mosaic Disease, Root Yields and Total Carotene Concentration of Yellow-Fleshed Cassava in Nigeria. International Journal of Agronomy, 2012, Article ID: 434675. https://doi.org/10.1155/2012/434675

[18] Malosetti, M., Ribaut, J. and van Eeuwijk, F.A. (2013) The Statistical Analysis of Multi-Environment Data: Modeling Genotype-by-Environment Interaction and Its Genetic Basis. Frontiers in Physiology, 4, Article No. 44. https://doi.org/10.3389/fphys.2013.00044 
[19] Falconer, D.S. and Mackay, T.F.C. (1996) Introduction to Quantitative Genetics. 4th Edition, Longman, New York.

[20] Masinde, E.A., Kimata, B., Ogendo, J.O., Mulwa, R.M.S., Mkamillo, G. and Maruthi, M.N. (2020) Developing Dual Resistant Cassava to the Two Major Viral Diseases. Crop Science. https://doi.org/10.1002/csc2.20374

[21] Ma'ali, S., Makgoga, W., Erasmus, J. and Swanepoel, S. (2019) Genotype-by-Environment Interaction and Yield Stability of Sunflower Hybrids across Production Environments in South Africa. South African Journal of Plant and Soil, 36, 271-278. https://doi.org/10.1080/02571862.2018.1558461

[22] Ssemakula, G. and Dixon, A.G.O. (2007) Genotype Environment Interaction, Stability and Agronomic Performance of Carotenoid-Rich Cassava Clones. Scientific Research and Essays, 2, 390-399.

[23] van Eeuwijk, F.A. (1995) Linear and Bilinear Models for the Analysis of Multi-Environment Trials: I. An Inventory of Models. Euphytica, 84, 1-7. https://doi.org/10.1007/BF01677551

[24] Gauch Jr., H.G. (1988) Model Selection and Validation for Yield Trials with Interaction. Biometrics, 44, 705-715. https://doi.org/10.2307/2531585

[25] Bernardo, R. (2010) Breeding for Quantitative Traits in Plants. 3rd Edition, Stemma Press, Woodbury.

[26] Hagos, H.G. and Abay, F. (2013) AMMI and GGE Biplot Analysis of Bread Wheat Genotypes in the Northern Part of Ethiopia. Journal of Plant Breeding and Genetics, $1,12-18$.

[27] Purchase, J.L., Hatting, H. and van Deventer, C.S. (2000) GenotypexEnvironment Interaction of Wheat (Triticum aestivum L.) in South Africa: Stability Analysis of Yield Performance. South African Journal of Plant and Soil, 17, 101-107. https://doi.org/10.1080/02571862.2000.10634878

[28] Nduwumuremyi, A., Melis, R., Shanahan, P. and Asiimwe, T. (2017) Interaction of Genotype and Environment Effects on Important Traits of Cassava (Manihot esculenta Crantz). The Crop Journal, 5, 373-386. https://doi.org/10.1016/j.cj.2017.02.004

[29] Tumuhimbise, R., Melis, R., Shanahan, P. and Kawuki, R. (2014) Genotype $\times$ Environment Interaction Effects on Early Fresh Storage Root Yield and Related Traits in Cassava. The Crop Journal, 2, 329-337. https://doi.org/10.1016/j.cj.2014.04.008

[30] Kundy, A.C., Mkamilo, G.S. and Misangu, R.N. (2014) Assessment and Selection of Superior Genotypes among Elite Cassava Genotypes by Farmers and Scientists in Southern Tanzania. Journal of Natural Sciences Research, 4, 24-32.

[31] Hahn, S. K., Terry, E. R. and Leuschner, K. (1980) Breeding Cassava for Resistance to Cassava Mosaic Disease. Euphytica, 29, 673-683.

https://doi.org/10.1007/BF00023215

[32] Hillocks, R.J., Raya, M. and Thresh, J.M. (1996) The Association Between Root Necrosis and Above-Ground Symptoms of Brown Streak Virus Infection of Cassava in Southern Tanzania. International Journal of Pest Management, 42, 285-289. https://doi.org/10.1080/09670879609372008

[33] Hillocks, R.J. and Maruthi, M.N. (2015) Post-Harvest Impact of Cassava Brown Streak Disease in Four Countries in Eastern Africa. Food Chain, 5, 116-122. https://doi.org/10.3362/2046-1887.2015.008

[34] Gondwe, F.M.T., Mahungu, N.M., Hillocks, R.J., Raya, M.D., Moyo, C.C., Soko, M.M., Chipungu, F.P. and Benesi, I.R.M. (2002) Economic Losses Experienced by Small-Scale Farmers in Malawi due to Cassava Brown Streak Virus Disease. Pro- 
ceedings of an International Workshop on Cassava Brown Streak Virus Disease: Past, Present, and Future, Mombasa, 27-30 October 2002, 28-36.

[35] Kawano, K. (1987) Inherent and Environmental Factors Related to Cassava Varietal Selection. In: Hershey, E., Ed., Cassava Breeding: A Multidisciplinary Review, International Center for Tropical Agriculture (CIAT), Cali, 207-226.

[36] Gauch, H.G. (2013) A Simple Protocol for AMMI analysis of Yield Trials. Crop Science, 53, 1860-1869. https://doi.org/10.2135/cropsci2013.04.0241

[37] Farshadfar, E. (2008) Incorporation of AMMI Stability Value and Grain Yield in a Single Non Parametric Index (GSI) in Bread Wheat. Pakistan Journal of Biological Sciences, 11, 1791-1796. https://doi.org/10.3923/pjbs.2008.1791.1796

[38] Farshadfar, E., Geravandi, M. and Vaisi, Z. (2012) Chromosomal Localization of QTLs Controlling Genotype $\times$ Environment Interactions in Barley. International Journal of Agriculture and Crop Sciences, 4, 317-324.

[39] Farshadfar, E., Mahmodi, N. and Yaghotipoor, A. (2011) AMMI Stability Value and Simultaneous Estimation of Yield and Yield Stability in Bread Wheat (Triticum aestivum L.). Australian Journal of Crop Science, 5, 1837-1844.

[40] Bose, L.K., Jambhulkar, N.N., Pande, K. and Singh, O.N. (2014) Use of AMMI and other Stability Statistics in the Simultaneous Selection of Rice Genotypes for Yield and Stability under Direct-Seeded Conditions. Chilean Journal of Agricultural Research, 74, 3-9. https://doi.org/10.4067/S0718-58392014000100001

[41] Mendiburu, F. (2020) Agricolae. R Package Version 1.3-3, Statistical Procedures for Agricultural Research. R Foundation for Statistical Computing, Vienna.

[42] Senkoro, C.J., Tetteh, F.M., Kibunja, C.N., Ndungu-Magiroi, K.W., Quansah, G.W., Marandu, A.E., Ley, G.J., Mwangi, T.J. and Wortmannn, C. S. (2018) Cassava Yield and Economic Response to Fertilizer in Tanzania, Kenya and Ghana. Agronomy Journal, 110, 1600-1606. https://doi.org/10.2134/agronj2018.01.0019

[43] Mtunguja, M.K., Laswai, H.S., Kanju, E., Ndunguru, J. and Muzanila, Y.C. (2016) Effect of Genotype and Genotype by Environment Interaction on Total Cyanide Content, Fresh Root, and Starch Yield in Farmer-Preferred Cassava Landraces in Tanzania. Food Science \& Nutrition, 4, 791-801. https://doi.org/10.1002/fsn3.345

[44] Dondeyne, S., Ngatunga, E.L., Cools, N., Mugogo, S. and Deckers, J. (2001) Landscapes and Soils of South Eastern Tanzania: Their Sustainability for Cashew, In: Topper, C.P. and Kasuga, L.J., Eds., Knowledge Transfer for Sustainable Tree Crop Development-A Case History of the Tanzanian Integrated Cashew Management Programme, BioHydrids Agrisystems Ltd., Reading, 229-239.

[45] Nordic Development Fund (2014) Coastal Profile for Tanzania Mainland 2014Thematic Volume I Including Threats Prioritisation. Investment Prioritisation for Resilient Livelihoods and Ecosystems in Coastal Zones of Tanzania Project Report. Nordic Development Fund, Helsinki.

[46] National Soil Service (1993) Revised Fertilizer Recommendations for Tanzania. In: Mowo, J.G., Floor, J., Kaihura, F.B.S. and Magoggo, J.P., Eds., Review of Fertilizer Recommendations for Tanzania Part 2, Tanzania Agricultural Research Institute (TARI)-Mlingano, Tanga, 15-30.

[47] Adjebeng-Danquah, J., Manu-Aduening, J., Gracen, V.E., Asante, I. K. and Offei, S. K. (2017) AMMI Stability Analysis and Estimation of Genetic Parameters for Growth and Yield Components in Cassava in the Forest and Guinea Savannah Ecologies of Ghana. International Journal of Agronomy, 2017, Article ID: 8075846. https://doi.org/10.1155/2017/8075846

[48] Pariyo, A., Baguma, Y., Alicai, T., Kawuki, R., Kanju, E., Bua, A., Omongo, C.A., Gib- 
son, P., Osiru, D.S., Mpairwe, D. and Tukamuhabwa, P. (2015) Stability of Resistance to Cassava Brown Streak Disease in Major Agro-Ecological Zones of Uganda. Journal of Plant Breeding Crop Science, 7, 67-78. https://doi.org/10.5897/JPBCS2013.0490

[49] Ogbe, F.O., Atiri, G.I., Dixon, A.G.O. and Thottappilly, G. (2003) Symptom Severity of Cassava Mosaic Disease in Relation to Concentration of African Cassava Mosaic Virus in Different Cassava Genotypes. Plant Pathology, 52, 84-91. https://doi.org/10.1046/j.1365-3059.2003.00805.x

[50] Mohammed, I.U., Abarshi, M.M., Muli, B., Hillocks, R.J. and Maruthi, M.N. (2012) The Symptom and Genetic Diversity of Cassava Brown Streak Viruses Infecting Cassava in East Africa. Advances in Virology, 2012, Article ID: 795697. https://doi.org/10.1155/2012/795697

[51] Ariyo, O.A., Dixon, A.G.O. and Atiri, G.I. (2003) Effect of Detopping on Disease Incidence and Symptom Severity of African Cassava Mosaic Virus Disease (ACMD) on Some Newly Developed Cassava Cultivars from Landraces Introgression. Acta Phytopathologica et Entomologica Hungarica, 38, 115-124. https://doi.org/10.1556/APhyt.38.2003.1-2.14

[52] Rabbi, I.Y., Hamblin, M.T., Kumara, P.L., Gedila, M.A., Ikpana, A.S., Jannink, J.L. and Kulakow, P.A. (2014) High-Resolution Mapping of Resistance to Cassava Mosaic Geminiviruses in Cassava Using Genotyping-by-Sequencing and Its Implications for Breeding. Virus Research, 186, 87-96. https://doi.org/10.1016/j.virusres.2013.12.028

[53] Masumba, E.A., Kapinga, F., Mkamilo, G., Salum, K., Kulembeka, H., Rounsley, S., Bredeson, J.V., Lyons, J.B., Rokhsar, S., Kanju, E., Katari, M.S., Myburg, A.A., van der Merwe, N.A. and Ferguson, M.E. (2017) QTL Associated with Resistance to Cassava Brown Streak and Cassava Mosaic Diseases in A Bi-Parental Cross of Two Tanzanian Farmer Varieties, Namikonga and Albert. Theoretical and Applied Genetics, 130, 2069-2090. https://doi.org/10.1007/s00122-017-2943-Z

[54] Kaweesi, T., Kawuki, R., Kyaligonza, V., Baguma, Y., Tusiime, G. and Ferguson, M.E. (2014) Field Evaluation of Selected Cassava Genotypes for Cassava Brown Streak Disease based on Symptom Expression and Virus Load. Virology Journal, 11, Article No. 216. https://doi.org/10.1186/s12985-014-0216-x

[55] Shirima, R. R., Legg, J. P., Maeda, D. G., Tumwegamire, S., Mkamilo, G., Mtunda, K., Kulembeka, H., Ndyetabula, I., Kimata, B.P., Matondo, D.G., Ceasar, G., Mushi, E., Sichalwe, K. and Kanju, E. (2020) Genotype by Environment Cultivar Evaluation for Cassava Brown Streak Disease Resistance in Tanzania. Virus Research, 286, Article ID: 198017. https://doi.org/10.1016/j.virusres.2020.198017

[56] Daryanto, S., Wang, L. and Jacinthe, P.A. (2017) Global Synthesis of Drought Effects on Cereal, Legume, Tuber and Root Crops Production: A Review. Agricultural Water Management, 179, 18-33. https://doi.org/10.1016/j.agwat.2016.04.022

[57] Santisopasri, V., Kurotjanawong, K., Chotineeranat, S., Piyachomkwan, K., Sriroth, K. and Oates, C.G. (2001) Impact of Water Stress on Yield and Quality of Cassava Starch. Industrial Crops and Products, 13, 115-129. https://doi.org/10.1016/S0926-6690(00)00058-3

[58] Maruthi, M.N., Kimata, B., Masinde, E.A. and Mkamilo, G. (2020) Effect of Time of Harvesting and Disease Resistance in Reducing Cassava (Manihot Esculenta Crantz) Yield Losses by Two Viral Diseases. Modern Concepts \& Developments in Agronomy, 6, 601-616. https://doi.org/10.31031/MCDA.2020.06.000628 


\section{Appendix}

Table S1. Mean, AMMI stability value (ASV), Genotype stability index (GSI) and rank (r) of CMD foliar symptoms for genotypes and sites.

\begin{tabular}{|c|c|c|c|c|c|c|c|c|c|c|c|c|c|c|c|}
\hline \multirow{2}{*}{ Genotype } & \multicolumn{5}{|c|}{ CMD 3 MAP } & \multicolumn{5}{|c|}{ CMD 6 MAP } & \multicolumn{5}{|c|}{ CMD 9 MAP } \\
\hline & Mean & ASV & GSI & rASV & rGSI & Mean & ASV & GSI & rASV & rGSI & Mean & ASV & GSI & rASV & rGSI \\
\hline Albert & 1.16 & 0.35 & 12.0 & 4 & 3 & 1.28 & 0.07 & 6.0 & 1 & 1 & 1.20 & 0.06 & 10.0 & 1 & 3 \\
\hline KBH 2002/26 & 1.02 & 0.72 & 28.0 & 12 & 15 & 1.02 & 0.61 & 28.0 & 6 & 15 & 1.03 & 0.69 & 28.0 & 12 & 15 \\
\hline КBH 2002/477 & 1.16 & 0.47 & 15.0 & 6 & 8 & 1.22 & 0.43 & 16.0 & 7 & 7 & 1.20 & 0.67 & 19.0 & 11 & 11 \\
\hline KBH 2002/482 & 1.13 & 0.30 & 14.0 & 2 & 7 & 1.34 & 0.60 & 14.0 & 11 & 5 & 1.25 & 0.09 & 7.0 & 2 & 1 \\
\hline КBH 2002/494 & 1.20 & 0.32 & 9.0 & 3 & 2 & 1.25 & 0.57 & 16.0 & 9 & 7 & 1.24 & 0.48 & 14.0 & 8 & 6 \\
\hline КBH 2002/66 & 1.18 & 0.82 & 20.0 & 13 & 11 & 1.14 & 0.23 & 15.0 & 3 & 6 & 1.16 & 0.33 & 17.0 & 6 & 7 \\
\hline КBH 96/1056 & 1.13 & 0.30 & 12.0 & 1 & 3 & 1.15 & 0.41 & 16.0 & 5 & 7 & 1.14 & 0.31 & 17.0 & 5 & 7 \\
\hline Kiroba & 1.20 & 1.34 & 21.0 & 16 & 12 & 1.29 & 0.77 & 18.0 & 14 & 12 & 1.26 & 1.17 & 18.0 & 15 & 10 \\
\hline Mahiza & 1.51 & 0.90 & 15.0 & 14 & 8 & 1.77 & 1.79 & 17.0 & 16 & 11 & 1.68 & 1.24 & 17.0 & 16 & 7 \\
\hline Mkumba & 1.05 & 1.09 & 28.0 & 15 & 15 & 1.03 & 0.78 & 30.0 & 15 & 16 & 1.05 & 1.06 & 29.0 & 14 & 16 \\
\hline Naliendele 134 & 1.33 & 0.72 & 13.0 & 11 & 5 & 1.41 & 0.58 & 12.0 & 10 & 3 & 1.39 & 0.56 & 11.0 & 9 & 4 \\
\hline NDL 2003/111 & 1.20 & 0.66 & 13.0 & 9 & 5 & 1.19 & 0.20 & 12.0 & 2 & 3 & 1.20 & 0.29 & 13.0 & 3 & 5 \\
\hline NDL 2003/31 & 1.24 & 0.39 & 8.0 & 5 & 1 & 1.27 & 0.30 & 10.0 & 4 & 2 & 1.25 & 0.30 & 8.0 & 4 & 2 \\
\hline NDL $2005 / 1471$ & 1.15 & 0.57 & 17.0 & 7 & 10 & 1.23 & 0.73 & 21.0 & 13 & 13 & 1.21 & 0.74 & 20.0 & 13 & 12 \\
\hline NDL $2005 / 1472$ & 1.03 & 0.70 & 25.0 & 10 & 14 & 1.08 & 0.48 & 21.0 & 7 & 13 & 1.06 & 0.57 & 24.0 & 10 & 14 \\
\hline Pwani & 1.03 & 0.59 & 22.0 & 8 & 13 & 1.22 & 0.42 & 16.0 & 12 & 7 & 1.06 & 0.46 & 20.0 & 7 & 12 \\
\hline Grand mean & 1.17 & & & & & 1.24 & & & & & 1.21 & & & & \\
\hline $\mathrm{CV}$ & 16.1 & & & & & 15.2 & & & & & 17.1 & & & & \\
\hline \multicolumn{16}{|l|}{ Environments } \\
\hline Chambezi 2013 & 1.51 & 0.98 & 32.0 & 29 & 17 & 1.74 & 0.72 & 24.5 & 23 & 5 & 1.63 & 0.93 & 31.0 & 30 & 11 \\
\hline Chambezi 2014 & 1.51 & 0.95 & 30.0 & 28 & 13 & 1.70 & 0.60 & 25.0 & 21 & 6 & 1.62 & 0.86 & 30.0 & 27 & 10 \\
\hline Chambezi 2015 & 1.51 & 1.00 & 31.0 & 30 & 14 & 1.73 & 0.71 & 25.0 & 22 & 6 & 1.62 & 0.92 & 32.0 & 28 & 16 \\
\hline Chambezi 2016 & 1.49 & 0.89 & 33.0 & 26 & 18 & 1.64 & 0.50 & 25.0 & 20 & 6 & 1.58 & 0.78 & 31.0 & 26 & 11 \\
\hline Chambezi 2017 & 1.15 & 0.28 & 20.0 & 11 & 5 & 1.15 & 0.46 & 33.0 & 18 & 15 & 1.14 & 0.44 & 36.0 & 19 & 24 \\
\hline Chambezi 2018 & 1.50 & 0.90 & 31.0 & 27 & 14 & 1.74 & 0.72 & 25.5 & 24 & 9 & 1.63 & 0.93 & 31.0 & 29 & 11 \\
\hline Chambezi mean & 1.45 & & & & & 1.62 & & & & & 1.54 & & & & \\
\hline Mtopwa 2013 & 1.07 & 0.10 & 24.0 & 1 & 8 & 1.06 & 0.19 & 27.5 & 5 & 10 & 1.08 & 0.11 & 23.5 & 1 & 5 \\
\hline Mtopwa 2014 & 1.06 & 0.14 & 28.0 & 3 & 11 & 1.06 & 0.21 & 31.5 & 7 & 14 & 1.06 & 0.17 & 39.0 & 11 & 28 \\
\hline Mtopwa 2015 & 1.06 & 0.14 & 26.0 & 2 & 10 & 1.06 & 0.20 & 30.5 & 6 & 13 & 1.06 & 0.17 & 37.0 & 10 & 26 \\
\hline Mtopwa 2016 & 1.00 & 0.36 & 47.5 & 18 & 30 & 1.02 & 0.47 & 49.0 & 19 & 30 & 1.01 & 0.43 & 48.0 & 18 & 30 \\
\hline Mtopwa 2017 & 1.00 & 0.36 & 46.5 & 17 & 29 & 1.14 & 0.34 & 29.0 & 13 & 11 & 1.16 & 0.34 & 31.0 & 16 & 11 \\
\hline Mtopwa 2018 & 1.04 & 0.39 & 45.0 & 19 & 28 & 1.12 & 0.11 & 21.5 & 4 & 4 & 1.14 & 0.16 & 26.0 & 8 & 6 \\
\hline Mtopwa mean & 1.04 & & & & & 1.07 & & & & & 1.09 & & & & \\
\hline
\end{tabular}




\section{Continued}

\begin{tabular}{|c|c|c|c|c|c|c|c|c|c|c|c|c|c|c|c|}
\hline Nachingwea 2013 & 1.08 & 0.20 & 25.0 & 5 & 9 & 1.05 & 0.22 & 35.0 & 8 & 19 & 1.07 & 0.14 & 29.0 & 3 & 7 \\
\hline Nachingwea 2014 & 1.08 & 0.21 & 29.0 & 7 & 12 & 1.04 & 0.25 & 39.0 & 10 & 27 & 1.07 & 0.14 & 29.0 & 4 & 7 \\
\hline Nachingwea 2015 & 1.08 & 0.20 & 23.0 & 4 & 7 & 1.05 & 0.23 & 35.0 & 9 & 19 & 1.07 & 0.16 & 33.0 & 9 & 19 \\
\hline Nachingwea 2016 & 1.08 & 0.32 & 35.0 & 14 & 19 & 1.09 & 0.46 & 38.0 & 17 & 25 & 1.09 & 0.34 & 38.0 & 17 & 27 \\
\hline Nachingwea 2017 & 1.01 & 0.32 & 43.0 & 15 & 26 & 1.05 & 0.33 & 39.0 & 11 & 27 & 1.08 & 0.25 & 34.5 & 12 & 20 \\
\hline Nachingwea 2018 & 1.03 & 0.34 & 43.0 & 16 & 26 & 1.06 & 0.43 & 38.5 & 16 & 26 & 1.04 & 0.33 & 43.0 & 14 & 29 \\
\hline Nachingwea mean & 1.06 & & & & & 1.06 & & & & & 1.07 & & & & \\
\hline Naliendele 2013 & 1.23 & 0.28 & 19.0 & 12 & 2 & 1.18 & 0.08 & 16.0 & 3 & 2 & 1.20 & 0.16 & 16.0 & 6 & 3 \\
\hline Naliendele 2014 & 1.23 & 0.29 & 21.0 & 13 & 6 & 1.18 & 0.07 & 16.0 & 2 & 2 & 1.20 & 0.15 & 13.0 & 5 & 2 \\
\hline Naliendele 2015 & 1.23 & 0.27 & 16.0 & 10 & 1 & 1.19 & 0.03 & 13.0 & 1 & 1 & 1.20 & 0.11 & 11.0 & 2 & 1 \\
\hline Naliendele 2016 & 1.14 & 0.23 & 19.0 & 8 & 2 & 1.10 & 0.41 & 35.0 & 15 & 19 & 1.13 & 0.31 & 32.0 & 13 & 16 \\
\hline Naliendele 2017 & 1.10 & 0.21 & 24.0 & 6 & 8 & 1.11 & 0.36 & 33.0 & 14 & 15 & 1.09 & 0.34 & 35.0 & 15 & 23 \\
\hline Naliendele 2018 & 1.14 & 0.26 & 19.0 & 9 & 2 & 1.12 & 0.34 & 29.5 & 12 & 12 & 1.15 & 0.16 & 23.0 & 7 & 4 \\
\hline Naliendele mean & 1.18 & & & & & 1.15 & & & & & 1.16 & & & & \\
\hline Segera 2013 & 1.10 & 0.61 & 36.5 & 22 & 22 & 1.25 & 0.74 & 33.5 & 25 & 17 & 1.19 & 0.57 & 36.0 & 23 & 24 \\
\hline Segera 2014 & 1.18 & 0.67 & 38.5 & 23 & 23 & 1.31 & 0.76 & 37.0 & 29 & 24 & 1.21 & 0.59 & 32.0 & 25 & 16 \\
\hline Segera 2015 & 1.14 & 0.70 & 38.5 & 24 & 23 & 1.32 & 0.74 & 35.0 & 27 & 19 & 1.22 & 0.55 & 34.5 & 22 & 20 \\
\hline Segera 2016 & 1.14 & 0.56 & 35.0 & 20 & 19 & 1.29 & 0.75 & 36.0 & 28 & 23 & 1.16 & 0.53 & 34.5 & 21 & 20 \\
\hline Segera 2017 & 1.12 & 0.58 & 35.0 & 21 & 19 & 1.24 & 0.74 & 33.5 & 26 & 18 & 1.20 & 0.52 & 31.0 & 20 & 11 \\
\hline Segera 2018 & 1.16 & 0.75 & 38.5 & 25 & 23 & 1.27 & 0.77 & 41.0 & 30 & 29 & 1.21 & 0.58 & 30.0 & 24 & 9 \\
\hline Segera mean & 1.14 & & & & & 1.28 & & & & & 1.20 & & & & \\
\hline
\end{tabular}

Table S2. Mean, AMMI stability value (ASV), Genotype stability index (GSI) and rank (r) of CBSD foliar symptoms for genotypes and sites

\begin{tabular}{|c|c|c|c|c|c|c|c|c|c|c|c|c|c|c|c|}
\hline \multirow{2}{*}{ Genotype } & \multicolumn{5}{|c|}{ CBSD 3 MAP } & \multicolumn{5}{|c|}{ CBSD 6 MAP } & \multicolumn{5}{|c|}{ CBSD 9 MAP } \\
\hline & Mean & ASV & GSI & rASV & rGSI & Mean & ASV & GSI & rASV & rGSI & Mean & ASV & GSI & rASV & rGSI \\
\hline Albert & 2.23 & 3.04 & 18.0 & 16 & 8 & 2.66 & 1.33 & 16.0 & 15 & 4 & 2.54 & 1.22 & 16. & 15 & 4 \\
\hline KBH 2002/26 & 1.13 & 0.15 & 14.0 & 2 & 3 & 1.42 & 0.82 & 19.0 & 10 & 10 & 1.28 & 0.44 & 15.0 & 5 & 3 \\
\hline КBH 2002/477 & 1.57 & 1.52 & 18.0 & 13 & 8 & 1.73 & 1.27 & 20.0 & 14 & 13 & 1.69 & 1.15 & 19.0 & 13 & 13 \\
\hline КBH 2002/482 & 1.25 & 0.38 & 14.0 & 5 & 3 & 1.34 & 0.80 & 18.0 & 8 & 8 & 1.33 & 0.64 & 17.0 & 8 & 5 \\
\hline КBH 2002/494 & 1.51 & 1.77 & 20.0 & 14 & 11 & 1.69 & 0.56 & 11.0 & 4 & 2 & 1.64 & 0.93 & 18.0 & 11 & 10 \\
\hline KBH 2002/66 & 1.26 & 0.64 & 16.0 & 8 & 7 & 1.27 & 0.35 & 12.0 & 1 & 3 & 1.26 & 0.37 & 14.0 & 3 & 2 \\
\hline КВН 96/1056 & 1.07 & 0.58 & 21.0 & 7 & 13 & 1.02 & 0.56 & 21.0 & 5 & 14 & 1.06 & 0.34 & 17.0 & 1 & 5 \\
\hline Kiroba & 1.15 & 0.20 & 14.0 & 3 & 3 & 1.52 & 0.80 & 17.0 & 9 & 7 & 1.39 & 0.60 & 15.0 & 7 & 3 \\
\hline Mahiza & 2.13 & 2.01 & 18.0 & 15 & 8 & 2.49 & 0.49 & 5.0 & 3 & 1 & 2.35 & 1.02 & 15.0 & 12 & 3 \\
\hline Mkumba & 2.31 & 0.98 & 13.0 & 12 & 2 & 2.27 & 1.72 & 19.0 & 16 & 10 & 2.36 & 1.37 & 18.0 & 16 & 10 \\
\hline Naliendele 134 & 1.48 & 0.04 & 8.0 & 1 & 1 & 2.09 & 0.92 & 16.0 & 12 & 4 & 1.83 & 1.17 & 19.0 & 14 & 13 \\
\hline NDL 2003/111 & 1.06 & 0.43 & 21.0 & 6 & 13 & 1.08 & 0.57 & 19.0 & 6 & 10 & 1.08 & 0.37 & 18.0 & 4 & 10 \\
\hline NDL $2003 / 31$ & 1.06 & 0.28 & 20.0 & 4 & 11 & 1.03 & 0.58 & 22.0 & 7 & 15 & 1.06 & 0.35 & 17.0 & 2 & 5 \\
\hline NDL 2005/1471 & 1.12 & 0.66 & 22.0 & 9 & 16 & 1.05 & 0.49 & 16.0 & 2 & 4 & 1.11 & 0.68 & 22.0 & 9 & 15 \\
\hline
\end{tabular}




\section{Continued}

\begin{tabular}{|c|c|c|c|c|c|c|c|c|c|c|c|c|c|c|c|}
\hline NDL 2005/1472 & 1.20 & 0.88 & 21.0 & 11 & 13 & 1.19 & 0.83 & 23.0 & 11 & 16 & 1.21 & 0.81 & 22.0 & 10 & 16 \\
\hline Pwani & 1.78 & 0.84 & 14.0 & 10 & 3 & 1.81 & 1.16 & 18.0 & 13 & 8 & 1.86 & 0.59 & 10.0 & 6 & 1 \\
\hline Grand mean & 1.46 & & & & & 1.61 & & & & & 1.57 & & & & \\
\hline $\mathrm{CV}$ & 25.1 & & & & & 20.8 & & & & & 19.3 & & & & \\
\hline \multicolumn{16}{|l|}{ Environments } \\
\hline Chambezi 2013 & 1.40 & 0.35 & 29.0 & 6 & 14 & 1.87 & 0.75 & 26.5 & 24 & 13 & 1.64 & 0.39 & 13.0 & 6 & 6 \\
\hline Chambezi 2014 & 1.40 & 0.31 & 21.0 & 2 & 6 & 1.89 & 0.81 & 28.5 & 26 & 18 & 1.66 & 0.35 & 8.0 & 3 & 2 \\
\hline Chambezi 2015 & 1.41 & 0.34 & 22.0 & 4 & 7 & 1.91 & 0.75 & 25.5 & 23 & 11 & 1.67 & 0.38 & 12.0 & 5 & 5 \\
\hline Chambezi 2016 & 1.41 & 0.35 & 24.0 & 7 & 9 & 1.79 & 0.64 & 14.0 & 9 & 1 & 1.60 & 0.29 & 11.0 & 1 & 3 \\
\hline Chambezi 2017 & 1.28 & 0.86 & 47.0 & 17 & 24 & 1.29 & 0.71 & 46.0 & 16 & 27 & 1.30 & 0.91 & 59.0 & 29 & 30 \\
\hline Chambezi 2018 & 1.40 & 0.34 & 26.5 & 5 & 12 & 1.89 & 0.75 & 24.5 & 22 & 6 & 1.65 & 0.37 & 11.0 & 4 & 3 \\
\hline Chambezi mean & 1.38 & & & & & 1.77 & & & & & 1.59 & & & & \\
\hline Mtopwa 2013 & 1.48 & 1.00 & 32.0 & 20 & 19 & 1.45 & 0.67 & 35.0 & 12 & 22 & 1.49 & 0.76 & 50.0 & 27 & 29 \\
\hline Mtopwa 2014 & 1.42 & 0.88 & 34.5 & 19 & 23 & 1.44 & 0.67 & 37.0 & 13 & 24 & 1.43 & 0.55 & 41.0 & 14 & 22 \\
\hline Mtopwa 2015 & 1.42 & 0.88 & 33.5 & 18 & 22 & 1.44 & 0.64 & 36.0 & 11 & 23 & 1.43 & 0.58 & 43.0 & 17 & 23 \\
\hline Mtopwa 2016 & 1.49 & 1.11 & 30.0 & 21 & 15 & 1.65 & 0.89 & 43.0 & 30 & 25 & 1.58 & 0.75 & 37.0 & 24 & 19 \\
\hline Mtopwa 2017 & 1.50 & 1.14 & 32.0 & 22 & 19 & 1.48 & 0.56 & 29.0 & 8 & 19 & 1.53 & 0.44 & 28.0 & 9 & 12 \\
\hline Mtopwa 2018 & 1.67 & 1.26 & 32.0 & 29 & 19 & 1.62 & 0.39 & 24.0 & 7 & 5 & 1.94 & 0.34 & 3.0 & 2 & 1 \\
\hline Mtopwa mean & 1.50 & & & & & 1.51 & & & & & 1.57 & & & & \\
\hline Nachingwea 2013 & 1.57 & 0.77 & 19.0 & 13 & 5 & 1.64 & 0.20 & 19.0 & 3 & 4 & 1.59 & 0.47 & 22.5 & 11 & 10 \\
\hline Nachingwea 2014 & 1.63 & 0.48 & 14.0 & 10 & 3 & 1.64 & 0.21 & 16.0 & 4 & 2 & 1.58 & 0.40 & 21.0 & 7 & 8 \\
\hline Nachingwea 2015 & 1.58 & 0.74 & 17.0 & 12 & 4 & 1.64 & 0.19 & 16.0 & 2 & 2 & 1.59 & 0.48 & 23.5 & 12 & 11 \\
\hline Nachingwea 2016 & 1.56 & 0.27 & 8.0 & 1 & 2 & 1.66 & 0.72 & 33.0 & 21 & 21 & 1.61 & 0.77 & 37.0 & 28 & 19 \\
\hline Nachingwea 2017 & 1.51 & 0.81 & 23.0 & 15 & 8 & 1.52 & 0.36 & 25.0 & 5 & 8 & 1.67 & 0.50 & 17.0 & 13 & 7 \\
\hline Nachingwea 2018 & 1.67 & 0.33 & 5.0 & 3 & 1 & 1.43 & 0.07 & 27.0 & 1 & 14 & 1.76 & 0.62 & 21.0 & 18 & 8 \\
\hline Nachingwea mean & 1.59 & & & & & 1.59 & & & & & 1.63 & & & & \\
\hline Naliendele 2013 & 1.47 & 0.66 & 24.0 & 11 & 9 & 1.40 & 0.86 & 55.0 & 27 & 28 & 1.44 & 0.71 & 48.0 & 23 & 28 \\
\hline Naliendele 2014 & 1.40 & 0.36 & 30.5 & 9 & 17 & 1.39 & 0.86 & 57.0 & 28 & 30 & 1.40 & 0.57 & 45.0 & 16 & 25 \\
\hline Naliendele 2015 & 1.40 & 0.35 & 28.0 & 8 & 13 & 1.40 & 0.87 & 56.0 & 29 & 29 & 1.40 & 0.56 & 43.0 & 15 & 23 \\
\hline Naliendele 2016 & 1.49 & 0.78 & 25.0 & 14 & 11 & 1.45 & 0.38 & 28.0 & 6 & 17 & 1.46 & 0.41 & 32.0 & 8 & 13 \\
\hline Naliendele 2017 & 1.43 & 0.84 & 30.0 & 16 & 15 & 1.59 & 0.64 & 29.0 & 10 & 19 & 1.51 & 0.45 & 32.0 & 10 & 13 \\
\hline Naliendele 2018 & 1.70 & 1.61 & 31.0 & 30 & 18 & 1.59 & 0.81 & 43.0 & 25 & 25 & 1.78 & 0.97 & 32.0 & 30 & 13 \\
\hline Naliendele mean & 1.48 & & & & & 1.47 & & & & & 1.49 & & & & \\
\hline Segera 2013 & 1.30 & 1.17 & 54.4 & 26 & 28 & 1.60 & 0.72 & 27.0 & 19 & 14 & 1.52 & 0.68 & 36.5 & 19 & 16 \\
\hline Segera 2014 & 1.38 & 1.15 & 48.5 & 24 & 26 & 1.76 & 0.72 & 25.0 & 17 & 8 & 1.55 & 0.75 & 45.5 & 25 & 26 \\
\hline Segera 2015 & 1.04 & 1.14 & 52.5 & 22 & 27 & 1.48 & 0.68 & 24.5 & 14 & 6 & 1.54 & 0.68 & 36.5 & 20 & 16 \\
\hline Segera 2016 & 1.64 & 1.20 & 54.5 & 28 & 29 & 1.88 & 0.72 & 25.0 & 17 & 8 & 1.58 & 0.68 & 36.5 & 20 & 16 \\
\hline Segera 2017 & 1.36 & 1.17 & 54.5 & 26 & 29 & 1.70 & 0.72 & 27.0 & 19 & 14 & 1.57 & 0.69 & 38.5 & 22 & 21 \\
\hline Segera 2018 & 1.32 & 1.15 & 47.5 & 24 & 25 & 1.66 & 0.68 & 25.5 & 15 & 11 & 1.52 & 0.75 & 46.5 & 26 & 27 \\
\hline Segera mean & 1.34 & & & & & 1.68 & & & & & 1.55 & & & & \\
\hline
\end{tabular}


Table S3. Mean, AMMI stability value (ASV), Genotype stability index (GSI) and rank (r) of root necrosis, root weight and dry matter content for genotypes and sites.

\begin{tabular}{|c|c|c|c|c|c|c|c|c|c|c|c|c|c|c|c|}
\hline \multirow{2}{*}{ Genotype } & \multicolumn{5}{|c|}{ Root necrosis } & \multicolumn{5}{|c|}{ Root weight } & \multicolumn{5}{|c|}{ Dry matter } \\
\hline & Mean & ASV & GSI & rASV & rGSI & Mean & ASV & GSI & rASV & rGSI & Mean & ASV & GSI & rASV & rGSI \\
\hline Albert & 4.11 & 1.34 & 13.0 & 12 & 3 & 17.36 & 4.92 & 27.0 & 11 & 14 & 27.18 & 2.65 & 25 & 10 & 14 \\
\hline KBH 2002/26 & 2.22 & 1.36 & 18.0 & 13 & 9 & 36.56 & 1.66 & 10.0 & 1 & 3 & 27.88 & 1.67 & 19 & 8 & 11 \\
\hline КBH 2002/477 & 1.58 & 0.56 & 17.0 & 7 & 8 & 42.86 & 3.60 & 12.0 & 6 & 4 & 28.69 & 0.46 & 5 & 2 & 2 \\
\hline KBH 2002/482 & 1.72 & 0.41 & 12.0 & 4 & 2 & 40.20 & 4.74 & 18.0 & 10 & 8 & 28.18 & 1.14 & 16 & 6 & 5 \\
\hline КBH 2002/494 & 1.58 & 1.23 & 22.0 & 11 & 15 & 43.23 & 5.54 & 16.0 & 12 & 7 & 28.77 & 0.13 & 2 & 1 & 1 \\
\hline KBH 2002/66 & 2.04 & 2.23 & 21.0 & 15 & 13 & 30.71 & 4.62 & 20.0 & 9 & 13 & 28.55 & 0.46 & 8 & 3 & 3 \\
\hline КBH 96/1056 & 1.46 & 0.75 & 24.0 & 9 & 16 & 44.18 & 17.59 & 19.0 & 16 & 11 & 28.40 & 3.14 & 17 & 11 & 6 \\
\hline Kiroba & 1.53 & 0.50 & 19.0 & 6 & 12 & 40.83 & 4.10 & 15.0 & 8 & 6 & 28.37 & 1.39 & 14 & 7 & 4 \\
\hline Mahiza & 3.08 & 1.11 & 13.0 & 10 & 3 & 20.03 & 2.86 & 18.0 & 3 & 8 & 28.62 & 3.53 & 17 & 13 & 6 \\
\hline Mkumba & 2.29 & 1.54 & 18.0 & 14 & 9 & 22.60 & 7.54 & 28.0 & 14 & 15 & 27.35 & 3.64 & 27 & 14 & 15 \\
\hline Naliendele 134 & 3.52 & 2.57 & 18.0 & 16 & 9 & 27.50 & 8.10 & 28.0 & 15 & 15 & 28.21 & 1.92 & 18 & 9 & 9 \\
\hline NDL 2003/111 & 1.50 & 0.16 & 15.0 & 1 & 5 & 51.86 & 3.15 & 6.0 & 5 & 2 & 28.30 & 3.43 & 20 & 12 & 12 \\
\hline NDL 2003/31 & 1.36 & 0.42 & 21.0 & 5 & 13 & 51.55 & 1.67 & 4.0 & 2 & 1 & 26.95 & 1.02 & 21 & 5 & 13 \\
\hline NDL 2005/1471 & 1.53 & 0.36 & 15.0 & 3 & 5 & 42.89 & 5.89 & 18.0 & 13 & 8 & 27.27 & 0.84 & 18 & 4 & 9 \\
\hline NDL 2005/1472 & 1.92 & 0.63 & 15.0 & 8 & 5 & 35.59 & 3.07 & 14.0 & 4 & 5 & 27.63 & 4.19 & 28 & 16 & 16 \\
\hline Pwani & 1.59 & 0.33 & 11.0 & 2 & 1 & 29.87 & 3.66 & 19.0 & 7 & 11 & 28.71 & 3.99 & 17 & 15 & 6 \\
\hline Grand mean & 2.06 & & & & & 36.1 & & & & & 28.1 & & & & \\
\hline $\mathrm{CV}$ & 36.2 & & & & & 43.8 & & & & & 16.9 & & & & \\
\hline \multicolumn{16}{|l|}{ Environments } \\
\hline Chambezi 2013 & 2.31 & 0.92 & 28.0 & 19 & 12 & 45.45 & 2.01 & 19.0 & 10 & 3 & 24.29 & 0.55 & 34.0 & 13 & 20 \\
\hline Chambezi 2014 & 1.56 & 0.17 & 30.0 & 2 & 14 & 25.57 & 1.38 & 26.0 & 4 & 8 & 27.62 & 0.92 & 35.0 & 18 & 22 \\
\hline Chambezi 2015 & 2.42 & 1.20 & 32.0 & 25 & 18 & 43.79 & 4.50 & 34.0 & 24 & 21 & 23.29 & 1.35 & 41.0 & 19 & 26 \\
\hline Chambezi 2016 & 3.06 & 1.51 & 31.0 & 30 & 16 & 60.27 & 7.06 & 29.0 & 26 & 10 & 16.96 & 0.31 & 38.0 & 8 & 24 \\
\hline Chambezi 2017 & 2.58 & 0.92 & 20.0 & 17 & 4 & 42.10 & 2.83 & 26.0 & 15 & 8 & 34.78 & 1.82 & 32.0 & 25 & 16 \\
\hline Chambezi 2018 & 2.10 & 1.06 & 33.0 & 22 & 19 & 54.05 & 7.24 & 33.0 & 27 & 17 & 36.35 & 0.82 & 20.0 & 17 & 3 \\
\hline Chambezi mean & 2.33 & & & & & 45.21 & & & & & 27.21 & & & & \\
\hline Mtopwa 2013 & 1.79 & 0.12 & 25.0 & 1 & 10 & 29.70 & 1.72 & 23.0 & 7 & 6 & 27.38 & 1.66 & 42.0 & 24 & 28 \\
\hline Mtopwa 2014 & 1.68 & 0.42 & 34.0 & 8 & 21 & 24.47 & 2.08 & 36.0 & 12 & 25 & 29.15 & 1.94 & 41.0 & 26 & 26 \\
\hline Mtopwa 2015 & 1.92 & 0.96 & 38.0 & 20 & 23 & 36.02 & 1.59 & 21.0 & 6 & 4 & 18.34 & 0.10 & 29.0 & 2 & 11 \\
\hline Mtopwa 2016 & 2.54 & 0.51 & 16.0 & 11 & 2 & 67.39 & 3.98 & 24.0 & 22 & 7 & 17.45 & 0.18 & 32.0 & 3 & 16 \\
\hline Mtopwa 2017 & 1.90 & 0.65 & 33.0 & 14 & 19 & 14.03 & 1.40 & 32.0 & 5 & 15 & 32.92 & 1.65 & 31.0 & 23 & 13 \\
\hline Mtopwa 2018 & 1.21 & 1.30 & 57.0 & 27 & 29 & 25.06 & 2.06 & 34.0 & 11 & 21 & 36.12 & 0.18 & 8.0 & 4 & 1 \\
\hline Mtopwa mean & 1.84 & & & & & 32.79 & & & & & 26.89 & & & & \\
\hline Nachingwea 2013 & 2.25 & 0.54 & 22.0 & 12 & 7 & 20.32 & 3.41 & 46.0 & 21 & 28 & 26.89 & 0.19 & 25.0 & 6 & 6 \\
\hline Nachingwea 2014 & 1.96 & 0.18 & 20.0 & 3 & 4 & 45.65 & 5.77 & 33.0 & 25 & 17 & 39.81 & 6.93 & 31.0 & 30 & 13 \\
\hline
\end{tabular}




\section{Continued}

\begin{tabular}{|c|c|c|c|c|c|c|c|c|c|c|c|c|c|c|c|}
\hline Nachingwea 2015 & 2.06 & 0.31 & 19.5 & 6 & 3 & 68.36 & 12.72 & 31.0 & 30 & 14 & 18.42 & 0.05 & 27.0 & 1 & 9 \\
\hline Nachingwea 2016 & 2.50 & 1.06 & 29.0 & 23 & 13 & 58.85 & 9.47 & 32.0 & 28 & 15 & 17.78 & 0.31 & 37.0 & 9 & 23 \\
\hline Nachingwea 2018 & 1.49 & 1.34 & 57.0 & 28 & 29 & 13.14 & 2.44 & 43.0 & 13 & 26 & 32.41 & 0.74 & 25.0 & 16 & 6 \\
\hline Nachingwea mean & 2.06 & & & & & 39.17 & & & & & 27.88 & & & & \\
\hline Naliendele 2013 & 2.06 & 1.24 & 39.5 & 26 & 24 & 27.60 & 1.75 & 30.0 & 9 & 12 & 22.47 & 0.44 & 33.0 & 10 & 19 \\
\hline Naliendele 2014 & 2.56 & 0.76 & 20.0 & 16 & 4 & 36.63 & 2.86 & 30.0 & 16 & 12 & 20.92 & 0.55 & 38.0 & 14 & 24 \\
\hline Naliendele 2015 & 1.85 & 0.92 & 41.0 & 18 & 26 & 18.97 & 1.74 & 34.0 & 8 & 21 & 35.98 & 3.97 & 34.0 & 29 & 20 \\
\hline Naliendele 2016 & 2.00 & 1.03 & 36.0 & 21 & 22 & 29.18 & 1.28 & 21.0 & 3 & 4 & 26.74 & 1.62 & 42.0 & 22 & 28 \\
\hline Naliendele 2018 & 1.75 & 1.12 & 49.0 & 24 & 28 & 38.02 & 3.16 & 33.0 & 20 & 17 & 30.77 & 1.41 & 31.0 & 20 & 13 \\
\hline Naliendele mean & 1.98 & & & & & 29.95 & & & & & 27.90 & & & & \\
\hline Segera 2013 & 1.87 & 0.47 & 31.5 & 10 & 17 & 13.56 & 3.14 & 47.5 & 19 & 30 & 30.72 & 0.53 & 23.5 & 11 & 4 \\
\hline Segera 2014 & 1.90 & 0.29 & 25.0 & 5 & 10 & 39.83 & 3.04 & 29.0 & 17 & 10 & 28.01 & 2.55 & 44.0 & 28 & 30 \\
\hline Segera 2015 & 1.87 & 0.47 & 30.5 & 9 & 15 & 13.56 & 3.14 & 46.5 & 18 & 29 & 30.72 & 0.53 & 24.5 & 12 & 5 \\
\hline Segera 2016 & 2.60 & 0.25 & 6.0 & 4 & 1 & 28.26 & 4.00 & 43.0 & 23 & 26 & 19.08 & 0.20 & 32.0 & 7 & 16 \\
\hline Segera 2017 & 2.39 & 0.71 & 23.0 & 15 & 8 & 57.18 & 9.61 & 34.0 & 29 & 21 & 38.13 & 1.99 & 29.0 & 27 & 11 \\
\hline Segera 2018 & 1.98 & 0.32 & 23.0 & 7 & 8 & 48.41 & 0.75 & 9.0 & 2 & 1 & 35.89 & 1.48 & 27.0 & 21 & 9 \\
\hline Segera mean & 2.10 & & & & & 33.47 & & & & & 30.43 & & & & \\
\hline
\end{tabular}

